\title{
The Impact of Renewable Energy, Urbanization, and Environmental Sustainability Ratings on the Environmental Kuznets Curve and the Pollution Haven Hypothesis
}

\author{
Chi-Hui Wang ${ }^{1}$ (D) Prasad Padmanabhan ${ }^{2}$ and Chia-Hsing Huang ${ }^{3, *(D)}$ \\ 1 Beijing Institute of Technology, Zhuhai 519088, China; wang_chihui@bitzh.edu.cn \\ 2 Greehey School of Business, St. Mary's University, San Antonio, TX 78228, USA; \\ ppadmanabhan1@stmarytx.edu \\ 3 SolBridge International School of Business, Daejeon 34613, Korea \\ * Correspondence: koreasing@solbridge.ac.kr
}

check for updates

Citation: Wang, C.-H.; Padmanabhan, P.; Huang, C.-H. The Impact of Renewable Energy,

Urbanization, and Environmental Sustainability Ratings on the Environmental Kuznets Curve and the Pollution Haven Hypothesis. Sustainability 2021, 13, 13747. https:/ / doi.org/10.3390/su132413747

Academic Editor: Antonio Boggia

Received: 10 November 2021 Accepted: 9 December 2021 Published: 13 December 2021

Publisher's Note: MDPI stays neutral with regard to jurisdictional claims in published maps and institutional affiliations.

Copyright: (c) 2021 by the authors. Licensee MDPI, Basel, Switzerland. This article is an open access article distributed under the terms and conditions of the Creative Commons Attribution (CC BY) license (https:/ / creativecommons.org/licenses/by/ $4.0 /)$.

\begin{abstract}
The impacts of renewable energy adoption and environmental sustainability ratings on the validity of the environmental Kuznets curve and the pollution haven hypothesis are examined using annual balanced panel data from 64 middle and low-income countries and spanning the 2005-2014 period. We show that the GDP per capita/ $\mathrm{CO}_{2}$ emissions per capita relationship is an inverse $\mathrm{S}$ curve for the full sample of low and middle-income countries and for each subsample. The renewable energy $/ \mathrm{CO}_{2}$ emissions per capita relationship is an inverse $\mathrm{N}$ curve for the full and the middle-income samples, but a V curve for the low-income sample. The foreign direct investment net inflows $/ \mathrm{CO}_{2}$ emissions per capita relationship is an $\mathrm{N}$ curve for the full and the middle-income samples, and a positive relationship in the low-income subsample. High levels of government environmental sustainability ratings in low-income countries with relatively higher incomes can attract foreign direct investment net inflows while reducing pollution. In contrast, middle-income countries with high environmental sustainability ratings can attract foreign direct investment net inflows only if they allow small increases in pollution.
\end{abstract}

Keywords: environmental Kuznets curve hypothesis; pollution haven hypothesis; environmental sustainability; renewable energy; low and middle-income countries; foreign direct investment net inflows

\section{Introduction}

In this paper, we examine the impact of two key attributes-the degree of adoption of renewable energy resources by a country, and whether high country environmental sustainability ratings alter two well-established relationships between: (a) gross domestic product per capita (GDP) and $\mathrm{CO}_{2}$ emissions per capita $\left(\mathrm{CO}_{2}\right)$-the environmental Kuznets curve), and (b) foreign direct investment net inflows (FDI) and $\mathrm{CO}_{2}$ (the pollution haven hypothesis). As a secondary objective, we also examine whether the degree of host country urbanization affects pollution in these countries and whether the degree of economic development impacts these relationships. We believe that to the best of our knowledge, the literature does not examine the impact of these intervening variables on the well-established relationships documented earlier, especially for low and middle-income countries.

There are persistent attempts to reduce global pollution by encouraging global industries and countries to adopt renewable energy sources [1-11]. Research also documents that these attempts have been successful mostly in developed countries. Studies indicate a negative renewable energy $/ \mathrm{CO}_{2}$ relationship in EU countries [2], and in Malaysia [1], while others find no relationship for Turkey [12]. Furthermore, recent evidence suggests that renewable energy adoption can successfully reduce pollution, at least in high-income countries [13]. Clearly, these results imply that the benefits of adoption of renewable energy 
sources may only extend to high-income countries and not to developing countries. However, despite recent literature on the renewable energy $/ \mathrm{CO}_{2}$ relationship, there seems to be ambiguity on the exact nature of this relationship as it pertains to the impact of renewable energy adoption on the environmental Kuznets curve and the pollution haven hypothesis, especially for low-and middle-income countries.

There is also extensive literature documenting the complex relationship between environmental pollution and GDP in host countries. While the literature adopts both linear and non-linear methodologies, there seems to be a consensus that the relationship between $\mathrm{CO}_{2}$ based pollution and GDP is inherently complex. For instance, economic growth levels of host countries matter: during the early (later) stages of economic growth, pollution output is associated positively (negatively) with GDP and is the environmental Kuznets curve [14-28]. Overall, the nature (and significance) of this relationship seems to depend on whether the sample country is developed or developing as well as on the selected time-period for examination. In this study, we introduce several new wrinkles: is this relationship impacted if the developing country adopts renewable energy sources? Studies involving high-income countries indicate that use of renewable energy can reduce carbon dioxide-based pollution. Do these results also extend to developing countries? To the best of our knowledge, this question has not been empirically examined in the literature. This is the first research question addressed in this study.

Next, extant literature suggests that FDI into host countries gravitates from countries with strict environment regulations into countries with lax environmental regulations, referred to as the pollution haven hypothesis [29-42]. Similarly, the pollution halo hypothesis contends that developing countries attract FDI from higher technology/high standard production process multinational firms, thereby potentially reducing host country $\mathrm{CO}_{2}$ emissions [43-45]. In this study, we contend that if host countries can reduce $\mathrm{CO}_{2}$ emissions by attracting firms making 'cleaner' investments, then the pollution haven relationship may be affected. Countries can signal their willingness to accept clean FDI (as well as their desire to use renewable energy sources) via the published environmental sustainability ratings. In this paper, we ask whether environmental sustainability ratings and renewable energy usage also alter the pollution haven/halo hypotheses. This is the second research question addressed in this study.

Finally, a significant third strand of literature examines how the degree of host country urbanization affects $\mathrm{CO}_{2}$ emissions. Empirical results using both linear and nonlinear methodology are mixed: some find a positive relationship $[46,47]$ while others document a negative relationship. Another segment suggests that country development levels matter [48]: a positive (negative) relationship is documented for low /middle (upper middle and high) income countries. Still more find complex relationships between the two variables emerge $[49,50]$ and still others find no relationship [51]. Based on these results, the degree of urbanization (particularly in developing countries) has the potential to alter the relationship between $\mathrm{CO}_{2}$ and host country GDP. This is the third research question addressed in this study.

Formally, this study will explore the impact of the adoption of renewable energy sources and the impact of urbanization on the environmental Kuznets curve and the pollution haven hypothesis for a sample of high-end and low-end middle-income countries for data over the 2005-2014 period. The empirical results presented here can enable us to better understand the impact of renewable energy adoption on the pollution/GDP relationship and the factors that influence foreign direct investment net inflows. Policy wise, are countries better off if they use renewable energy sources? If developing countries adopt renewable energy sources and possess high environmental sustainability ratings, then there is potential to lower pollution and attract non-polluting foreign direct investment net inflows. In turn, these developments can increase GDP while reducing pollution-a very desirable outcome. We believe that there is paucity of research relating renewable adoption and environmental sustainability ratings to the well-established relationships referenced above, especially for low and middle-income countries. 
Formally, the research questions addressed in this study are as follows:

(a) Does the adoption of renewable energy sources alter the environmental Kuznets curve relationship and the pollution haven relationship for low- and middle-income sample countries?

(b) Does the adoption of strong environmental sustainability ratings by host countries assist in reducing pollution while attracting non-pollution inflows into low and middle-income countries?

(c) Does the degree of urbanization alter the relationships of interest?

The paper is organized as follows. The literature review in Section 2 is followed by sample description in Section 3. The adopted research methodology and empirical results are presented in Section 4. Discussion of results in Section 5 is followed by conclusion in Section 6.

\section{Literature Review}

\subsection{Literature Related to the Validity of the Environmental Kuznets Curve}

The extant literature documents a confusing array of linear and non-linear relationships between GDP and $\mathrm{CO}_{2}$ in host countries. For instance, using nonlinear OLS models, Tucker documents evidence that GDP and $\mathrm{CO}_{2}$ emissions were positively related for a group of low, middle, and high-income countries [52]. In contrast, other researchers document a plethora of complex relationships involving the variables of interest. For instance, using nonlinear methodology, Onafowora and Owoye detect an inverted " $U$ " shape relationship for Japan and Korea (developed countries), and an " $\mathrm{N}$ " shape for developing countries (Brazil, China, Egypt, Mexico, Nigeria, and South Africa [53]). More recently, and using nonlinear methodology, Apergis document an inverted U shape relationship for 12 of 15 developed countries while controlling for their development growth over the 1960-2010 period [54]. Similarly, and using a nonlinear methodology, Youssef, Hammoudeh, and Omri document that an inverted $U$ shape exists for 56 sample countries that accommodate high-, middle-, and low-income countries in the sample [55].

Finally, using OECD country data and nonlinear methodology, Churchill et al. found that the precise shape of the relationship is sample specific [56]. Similarly, using data from eight OECD countries, Isik et al. found that the environmental Kuznets curve (EKC) hypothesis is supported for data from four of eight sample countries by the undecomposed GDP, but not by the decomposed GDP [18]. Next, using data from five emerging countries (Brazil, India, China, South Africa, and Turkey), Dogan et al. also found that the environmental Kuznets curve hypothesis is not supported when considering environmental degradation [19].

Overall, it appears that the data show preference for nonlinear methodology, presumably because it best captures the underling complex relationship. Furthermore, the exact economic development $/ \mathrm{CO}_{2}$ relationship seems to depend on sample periods/countries.

\subsection{Does Urbanization Impact the $\mathrm{CO}_{2}$ Emissions/Economic Development Relationship?}

Another literature stream examines how the degree of host country urbanization affects $\mathrm{CO}_{2}$ and on whether this relationship depends on the degree of economic development of host countries. Several studies (using linear models) document that urbanization positively influences $\mathrm{CO}_{2}$ in sample countries [46,47] while others have found a negative relationship [57]. Another segment suggests that the impact of urbanization on $\mathrm{CO}_{2}$ depends on the degree of economic development of the host country. For instance, the impact of urbanization on $\mathrm{CO}_{2}$ differs depending on the level of economic development of host countries [48]. Both researchers find a positive $\mathrm{CO}_{2} /$ urbanization relationship in low and middle-income countries but a negative $\mathrm{CO}_{2}$ / urbanization relationship in the upper middle and high-income countries. Results are similarly mixed when nonlinear models are used. Some document an inverted U relationship for some developing country targets $[49,50]$, while others find no relationship using emerging country data [51]. Clearly, the degree of urbanization in developing countries has the potential to alter the relationship be- 
tween $\mathrm{CO}_{2}$ and host country GDP. Recent evidence seems to favor a nonlinear formulation over the linear one and indicate that the relationship may be inherently nonlinear.

\subsection{FDI and $\mathrm{CO}_{2}$ Emissions}

The link between FDI and $\mathrm{CO}_{2}$ remains empirically uncertain. Clear evidence suggests FDI from pollution strict countries gravitate towards countries with lax pollution control countries [31-34,36,40,58]. This is the pollution haven hypothesis. Furthermore, some host countries attract FDI from higher technology/high standard production process multinational firms, which can reduce host country $\mathrm{CO}_{2}$ [43-45]. This is the pollution halo hypothesis. However, Bulus and Koc find that there is no significant relationship between FDI and $\mathrm{CO}_{2}$ in Korea [39].

If host countries can reduce $\mathrm{CO}_{2}$ by attracting firms making 'cleaner' investments, then this influences the pollution haven hypothesis. If host countries promote renewable energy, then this can alter well-established relationships between GDP, economic development, $\mathrm{CO}_{2}$, host country urbanization levels, and FDI.

\subsection{Renewable Energy Adoption in High, Middle-, and Low-Income Developing Countries}

Research documents a negative renewable energy/ $\mathrm{CO}_{2}$ relationship in EU countries [2], in Malaysia [1], and in Portugal, Ireland, Italy, Greece, and Spain [11]. However, others find no relationship for Turkey [12]. Recent evidence suggests that renewable energy consumption is negatively associated with $\mathrm{CO}_{2}$ only for the high-income country subsamples [13]. In contrast, unlike the results reported for high-income countries, the renewable energy consumption $/ \mathrm{CO}_{2}$ relationship is documented to be an inverted $\mathrm{N}$ curve in the short run in Egypt [10]. However, Gyamfi et al. found no relationship between renewable energy consumption and $\mathrm{CO}_{2}$ in the short run in Brazil, China, India, Indonesia, Mexico, Russia, and Turkey [9]. Taken together, these results imply that the benefits of adoption of renewable energy sources may only extend to high-income countries and not to low-income countries.

\subsection{High Environmental Sustainability Ratings on Pollution in Middle and Low-Income Developing Countries}

Environmental policies can encourage renewable energy consumption, subsequently generating sustainable economic development [59]. Renewable energy adoption can negatively impact $\mathrm{CO}_{2}$ while positively influencing local income, energy security, social economics, and the environment [60]. Low and middle-income countries may face socio-economic and other barriers towards adoption of renewable energy resources. Consequently, enforced government environmental policy prescriptions can reduce perceived/ actual barriers towards renewable energy adoption [61]. Low/middle-income countries with strong special-interest groups do hinder $\mathrm{CO}_{2}$ reduction efforts $[62,63]$. In contrast, high-income countries receive support from private/public stakeholders for use of renewable energy to reduce pollution while maintaining long-run economic growth [60]. Le, Chang, and Park show that proper governmental environmental policies can reduce $\mathrm{CO}_{2}$ but only in high-income countries [13]. Finally, Sys et al. show that petrochemical lobbies shape government environmental regulation policies to inhibit the use of renewable energy in these countries [64]. Others argue that coordination between environmental regulatory/governance/energy technology policies can generate sustainable economic development $[65,66]$.

In this research, we expect our results to differ from those presented in Le, Chang, and Park [13]. We argue that the correlation between better pollution reduction technologies that reduce $\mathrm{CO}_{2}$, and effective (and enforced) governmental environmental regulation policies can enable the successful adoption of renewable energy resources to generate economic growth in low- and middle-income countries while reducing pollution output. In contrast, Le, Chang, and Park found that governmental economic policy initiatives on adoption of renewable energy resources are uncorrelated with economic growth in low and middle-income developing countries [13]. 
In summary, the extant literature presents evidence of a complex relationship between host country $\mathrm{CO}_{2}$, GDP, economic development, and urbanization levels, independent of methodology used. Despite these conclusions, we believe that inclusion of a renewable energy adoption proxy can alter these relationships further. Presumably, renewable energy is pollution friendly. Stated differently, renewable energy adoption by hosts can serve as an intervening variable in influencing stated relationships. We investigate whether the introduction of the renewable energy variable alters the $\mathrm{CO}_{2}$ /state of development/GDP/urbanization relationship for middle-income and low-income countries. We aim to present evidence that effective coordination between governmental policies and the adoption of renewable energy resources can enhance economic growth in low and middle-income developing countries while reducing global pollution.

\section{Sample Data}

Using the most recent publicly available World Bank data, the selected sample consists of annual balanced panel data from $64 \mathrm{mid}$ and low-income (39 middle income and 25 low income) countries and spans the 2005 to 2014 period. We selected carbon dioxide emissions per capita (captured by $\mathrm{CO}_{2}$ as stated earlier) as the pollution proxy and the dependent variable in the study. Following prior literature, the selected independent variables for inclusion are GDP (as defined earlier, this is gross domestic product per capita), renewable energy consumption (REC), urbanization (URBAN), CPIA business regulatory environment rating (BRER), CPIA policy and institutions for environmental sustainability rating (PIESR), CPIA transparency, accountability, and corruption in the public sector rating (TACR), and foreign direct investment net inflows (FDI).

The $\mathrm{CO}_{2}$ data are metric tons per capita. GDP data are in constant 2010 U.S. dollars. REC is the renewable energy consumption as a percentage of total energy consumption. URBAN is percentage of urban population growth minus percentage of population growth. A higher CPIA business regulatory environment rating (BRER) represents a better regulatory environment. A high CPIA policy and institutions for environmental sustainability rating (PIESR) represents a better environmental sustainability. A high CPIA transparency, accountability, and corruption in the public sector rating (TACR) represents a better public sector environment for the country. FDI data are in current U.S. dollars using natural logarithms. Variable definitions are shown in Table 1. For classification based on income levels, we adopted the World Bank scheme. Data are retrieved from the World Bank database (http:/ / www.worldbank.org/, accessed on 1 November 2021).

Table 1. Variable definitions.

\begin{tabular}{cl}
\hline Variables & \multicolumn{1}{c}{ Definitions } \\
\hline $\mathrm{CO}_{2}$ & $\mathrm{CO}_{2}$ emissions data are metric tons per capita \\
GDP & Gross domestic product per capita data (in logs), in constant 2010 U.S. dollars \\
REC & Renewable energy consumption as a percentage of total energy consumption \\
URBAN & Percentage of urban population growth minus percentage of population growth \\
BRER & Country Policy and Institutional Assessment (CPIA) business regulatory environment rating score \\
PIESR & CPIA policy and institutions for environmental sustainability rating score \\
TACR & CPIA transparency, accountability, and corruption in the public sector score \\
FDI & Foreign direct investment net inflows (FDI) data are in log of current U.S. dollars \\
\hline
\end{tabular}

Sample descriptive statistics and correlations are presented in Appendix A Table A1 (descriptive statistics) and Table A2a (sample countries). Next, we test mean differences between the low and middle-income countries across key sample variables and present these results in Table A2b. Finally, Table A3a (correlation coefficients for the entire sample), Table A3b (correlation coefficients for the low-income country sample), and Table A3c (correlation coefficients for the middle-income country sample) are presented.

Based on the presented preliminary statistics, some key observations are made. First, from Table A1, average $\mathrm{CO}_{2}$ and average GDP seem to be lower for low-income coun- 
tries in the sample than for middle-income countries. There also seems to be a greater degree of urbanization in sample low-income countries than in sample middle-income countries. Curiously, there seems to be a higher degree of adoption of renewable energy (as a percentage of total energy consumption) in low-income sample countries than in middle-income sample countries. FDI also seems to be higher in middle-income countries when compared to low-income countries. These preliminary findings suggest some clear differences between the two subgroups with respect to the dependent variable and key independent variables. These statistics seem to imply that economic development leads to increased $\mathrm{CO}_{2}$ and urbanization, and lowered rate of adoption of renewable energy. Next, the results presented in Table A2b suggest significant differences in sample means all key variables (except for FDI) across the two groups and justify partitioning the data into low and middle-income countries.

Finally, the correlation matrix for the full sample presented in Table A3a provides some interesting findings. First, $\mathrm{CO}_{2}$ is negatively correlated with $\mathrm{REC}$, which suggests that $\mathrm{CO}_{2}$ can be reduced with the adoption of renewable energy. $\mathrm{Next} \mathrm{CO}_{2}$ are also negatively associated with URBAN in sample countries, suggesting that urbanization can mean higher $\mathrm{CO}_{2}$. Finally, the negative correlation between GDP and REC (and between GDP and $\mathrm{CO}_{2}$ ) may indicate that economic development can unfortunately lead to decreased adoption of renewable energy sources in sample countries.

We now split the sample into low-income and middle-income countries. Correlation results from Table A3b (low-income countries) and Table A3c (middle-income countries) suggest that there are differences only in the relationship between $\mathrm{CO}_{2}$ and GDP, and between $\mathrm{CO}_{2}$ and URBAN. $\mathrm{CO}_{2}$ is significantly negatively correlated with GDP for middleincome countries, whereas they are significantly positively correlated for the full sample and the low-income countries. In addition, $\mathrm{CO}_{2}$ is negatively correlated (but not statistically significantly) with URBAN for the middle-income sample whereas they are significantly negatively correlated for the other samples. These findings suggest that whereas economic development leads to higher $\mathrm{CO}_{2}$ in middle-income countries, urbanization does not seem to influence $\mathrm{CO}_{2}$ in such countries. However, since the literature indicates a more complex set of nonlinear relationships between the variables of interest, we will investigate further using appropriate nonlinear methodology described in the next section.

\section{Research Methodology and Empirical Results}

\subsection{Research Methodology}

Specifically, we utilize the Panel Smooth Transition Regression (PSTR) methodology developed by González, Teräsvirta, and Van Dijk [67] and Fok, Van Dijk, and Franses [68]. The PSTR model is a generalized version of the Panel Threshold Regression (PTR) model and used extensively where there is a need to generate smooth "transitions" from one economic regime to another.

The purpose of this paper is to examine whether the degree of adoption of renewable energy resources and published country environmental sustainability ratings separately alter the relationships between GDP and $\mathrm{CO}_{2}$ (the environmental Kuznets curve), and between FDI and $\mathrm{CO}_{2}$ (the pollution haven hypothesis). Since economic conditions can change over time, i.e., via a structural break and/or nonlinearity, model parameters may be time dependent. Given these conditions, the PSTR model is ideally suited to examine the research questions. Specifically, the PSTR model accommodates a small number of extreme regimes with extreme values of the transition function and allows for heterogeneity and time instability of variables while accommodating a variety of nonlinear paths. Sample country data used exhibit differences across independent variables and possible nonlinearity of sample variables. Hence, we adopt the PSTR methodology to examine the linkages between economic growth, renewable energy, environmental sustainability regulations, and $\mathrm{CO}_{2}$ for the entire sample and separately for low-income and middle-income sample countries. 
Following prior literature, a two-step procedure was used for the overall data and for each of the two subsamples. As a first step, we determined whether each variable was stationarity for the overall sample and for each subsample by using the panel unit root test. Next, the balanced panel variables were used to examine the relationship between $\mathrm{CO}_{2}$ and the other independent variables. Since we used the nonlinear specification, there was no need for the "coefficient stability assumption" as required for the linear model. Hence, we allowed for changing parameter estimates by using the PSTR model.

In our case, the simplest PSTR model containing two extreme regimes and one transition function is as follows:

$$
y_{i t}=\mu_{i}+\beta_{0}^{\prime} x_{i t}+\beta_{1}^{\prime} x_{i t} g\left(q_{i t} ; \gamma, c\right)+\varepsilon_{i t}
$$

where $y_{\text {it }}$ is $\mathrm{CO}_{2}\left(\mathrm{CO}_{2}\right.$ emissions per capita); $\mathrm{x}_{\mathrm{it}}$ is a $\mathrm{k}$-dimensional vector of time-varying exogenous variables described earlier but stated again here for easy reference: GDP (GDP per capita), renewable energy consumption (REC), urbanization (URBAN). CPIA business regulatory environment rating score (BRER), CPIA policy, and institutions for environmental sustainability rating score (PIESR), CPIA transparency, accountability, and corruption in the public sector rating score (TACR), and FDI (foreign direct investment net inflows), $\mathrm{i}=1, \ldots, \mathrm{N} ; \mathrm{t}=1, \ldots, \mathrm{T}$; and $\mathrm{N}$ and $\mathrm{T}$ are the cross section and time dimensions of the panel, respectively. $\mathrm{g}(\cdot)$ is the transition function that depends on slope parameters $\gamma$ and location parameters $c$. $\mathrm{q}_{\mathrm{it}}$ is the transition variable GDP. The transition function $\mathrm{g}(\cdot)$ is normalized to be bounded between 0 and 1 ; these extreme values are associated with regression coefficients $\beta_{0}^{\prime}$ and $\beta_{0}^{\prime}+\beta_{1}^{\prime}$ [69-71]. The multi-level PSTR model is a generalized version of the PSTR model that allows for multiple regimes and is captured as:

$$
y_{i t}=\mu_{i}+\beta_{0}^{\prime} x_{i t}+\sum_{j=1}^{r} \beta_{j}^{\prime} x_{i t} g_{j}\left(q_{i t}^{j} ; \gamma_{j}, c_{j}\right)+\varepsilon_{i t}
$$

where the transition functions $g_{j}\left(q_{i t}^{j} ; \gamma_{j}, c_{j}\right), j=1, \cdots, r$ depend on slope parameters $\gamma$, and on location parameters $c_{j}[67,68]$.

The PSTR modeling process requires 3 stages, namely, the specification, estimation, and evaluation stages. The homogeneity tests and the selection of the transition variable $\mathrm{q}_{\mathrm{it}}$ are integral components of the specification stage. The parameters are estimated by a nonlinear least square method (the estimation stage). The number of regimes, i.e., the $r$ in Equation (2) of the panel, are specified in the evaluation state.

\subsection{Nonlinearity Tests}

The results of the cross-sectional dependence tests are shown in Table A4. Both the Breusch-Pagan LM test and the Pesaran scaled LM test show that the null hypothesis of no cross-sectional dependence between sample variables is rejected at the $1 \%$ level for the full, low-income, and middle-income samples. The Pesaran CD test shows that the null hypothesis can be rejected at the $10 \%, 5 \%$, and $1 \%$, respectively, for the full, low-, and middle-income samples.

Next, panel unit root tests across sample variables using the Levin, Lin, and Chu $t$ test [72] are shown in Table A5, and they show that the unit root process is rejected at the $1 \%$ level for all variables, including $\mathrm{CO}_{2}, \mathrm{GDP}, \mathrm{REC}, \mathrm{URBAN}, \mathrm{BRER}, \mathrm{PIESR}, \mathrm{TACR}$, and FDI. The linearity tests for each independent variable, including the Wald tests (LM), the Fisher tests (LMF), and the LRT tests (LRT) in Table A6 show that the linearity hypotheses are rejected at $1 \%$ level. The optimal combination of $r(m)$ for the transition function is shown in Table A7 [69].

The results of linearity tests for the full sample and for each of the low-income and the middle-income subsamples and using GDP as the transition variable, are shown in Table A6. Since all linearity tests (the LM, LMF, and LRT tests) reject the linearity hypothesis at the $1 \%$ level, nonlinear models are used to examine the relationships between the dependent variable and independent variables with GDP as the transition variable. 
The number of regimes for the full sample, low and middle-income country subsamples are shown in Table A7 [69]. The optimal number of regimes for the full sample, the low-income country subsample, and the middle-income country subsample are respectively 2(1), 1(1), and 2(1). Table A8 shows checks for any remaining nonlinearity. Results show that the null hypotheses, PSTR with $\mathrm{r}=1$, are rejected at $1 \%$ only for the full sample and the middle-income subsample. Based on the RSS test results, the best fit for the full sample, low-income country subsample, and the middle-income country subsample are $r=2, r=1$, and $r=2$, respectively. In the next section, we present empirical tests using the PSTR nonlinear methodology for the overall sample and for each of the subsamples.

\subsection{PSTR Model Estimation Results}

The PSTR model estimation results with GDP as the transition variable are shown in Table A9. For the full sample and for each of the subsamples, two sets of PSTR model estimation results (the basic model (first column of Table A9) and the model with the interaction term (second column of Table A9) are presented. Results indicate that the $\mathrm{CO}_{2}$ -GDP relationship varies across the full sample and the subsamples across regimes. In the full sample, the stated relationship is negative (significantly negative, significantly positive) for regimes $1(2,3)$. Second, the relationships between $\mathrm{CO}_{2}$ and other sample variables similarly vary across samples and regimes. For instance, REC is significantly negatively (significantly positively, significantly negatively) related to $\mathrm{CO}_{2}$ for regimes $1(2,3)$. Third, URBAN is significantly negatively (positively, positively) related to $\mathrm{CO}_{2}$ in regimes $1(2,3)$. Fourth, CPIA policy and institutions for environmental sustainability rating (PIESR) is significantly positively (significantly negatively, significantly positively) related to $\mathrm{CO}_{2}$ in regimes $1(2,3)$. The dummy variable, DPIESR, is assigned a value of 1 if the PIESR of a country is greater than or equal to the PIESR median value of all sample countries, otherwise DPIESR $=0$. This interaction term captures the conditional effect of FDI on $\mathrm{CO}_{2}$ for countries with high levels of environmental sustainability ratings. The results presented under column two in Table A9 for the full sample show that the interaction term (DPIESR* FDI) is significantly positively (negatively, significantly positively) related to $\mathrm{CO}_{2}$ in regimes $1(2,3$, and 4$)$.

Clearly, the full sample results differ from subsample results. For instance, the $\mathrm{CO}_{2} / \mathrm{GDP}$ relationship and the interaction term (which examines the impact of environmental sustainability ratings on the $\mathrm{FDI} / \mathrm{CO}_{2}$ relationship) are subsample specific. Estimates for the low-income subsample suggest a significantly negative relationship between the dependent variable and GDP for both regimes whereas results for the middleincome subsample are regime specific with sign changes. A positive (negative) sign on the interaction term shows that for countries with high environmental sustainability ratings, foreign direct investment net inflows positively (negatively) correlate with $\mathrm{CO}_{2}$.

\subsection{Marginal Effects: Full Sample}

Table A10 presents the marginal effects separately for the full sample and for each subsample for the basic and the interaction term models. The overall results are presented in summary form in Table 2.

For the full sample, the marginal effects of GDP on $\mathrm{CO}_{2}$ are $-0.045,-0.237$, and -0.153 for regimes $1(2,3)$, respectively (an inverse $S$ curve) with a smaller negative (larger negative, smaller negative) slope in regime $1(2,3)$. The marginal effects of renewable energy on $\mathrm{CO}_{2}$ are $-0.009,0.004$, and -0.014 for regimes $1(2,3)$, respectively (an inverse $\mathrm{N}$ curve) with a negative (positive, negative) slope in regime $1(2,3)$. Next, the marginal effects of URBAN on $\mathrm{CO}_{2}$ are $-0.095,-0.001$, and 0.012 for regimes $1(2,3)$, respectively (a V curve) with negative slopes in regimes 1 and 2 , and a positive slope in regime 3 . Finally, for the full sample, the marginal effects of FDI on $\mathrm{CO}_{2}$ are $0.002,-0.007$, and 0.007 for regimes 1 $(2,3)$, respectively (an $\mathrm{N}$ curve) with a positive (negative, positive) slope in regime $1(2,3)$. 
Table 2. Summary of PSTR estimation results.

\begin{tabular}{|c|c|c|c|c|}
\hline Independent Variable & Regimes & Full Sample & $\begin{array}{l}\text { Low-Income Country } \\
\text { Sample }\end{array}$ & $\begin{array}{l}\text { Middle-Income Country } \\
\text { Sample }\end{array}$ \\
\hline \multirow{3}{*}{ GDP } & Regime 1 & Negative; Not Significant & Negative; Significant & Negative; Not Significant \\
\hline & Regime 2 & Negative; Significant & Negative; Significant & Negative; Significant \\
\hline & Regime 3 & Positive; Significant & - & Positive; Significant \\
\hline \multirow{3}{*}{ REC } & Regime 1 & Negative; Significant & Negative; Significant & Negative; Significant \\
\hline & Regime 2 & Positive; Significant & Positive; Significant & Positive; Significant \\
\hline & Regime 3 & Negative; Significant & - & Negative; Significant \\
\hline \multirow{3}{*}{ URBAN } & Regime 1 & Negative; Significant & Negative; Not Significant & Negative; Significant \\
\hline & Regime 2 & Positive; Not Significant & Negative; Not Significant & Positive; Significant \\
\hline & Regime 3 & Positive; Not Significant & - & Positive; Not Significant \\
\hline
\end{tabular}

Note: Significant results are bolded.

Collectively, these results indicate a strong nonlinear relationship between the dependent variable and variables of interest. They also show that the subsample results are generally different from the full sample marginal effect results. For the full sample, an increase in FDI is positively associated with $\mathrm{CO}_{2}$ when GDP is low and support the pollution haven hypothesis. In contrast, an increase in FDI is negatively associated with $\mathrm{CO}_{2}$ up to a threshold increase in GDP. Beyond this threshold, increases in FDI are positively associated with $\mathrm{CO}_{2}$, and reaffirms the nonlinear nature of this relationship among sample variables.

Next, the interaction term captures the impact of the environmental sustainability ratings on FDI. For the full sample (for countries with high environmental sustainability ratings), the marginal effects of FDI on $\mathrm{CO}_{2}$ are respectively $0.005,-0.5365,-0.5336$, and -0.078 in regimes $1(2,3,4)$, and suggest that for high rating countries, FDI positively (negatively) correlate with $\mathrm{CO}_{2}$ only when GDP is low (high). Clearly, high GDP countries adopting measures to increase environmental sustainability ratings can benefit with increased FDI while reducing $\mathrm{CO}_{2}$. If low GDP countries enact enforceable policies to increase their environmental profiles, they can attract FDI while reducing pollution.

\subsection{Marginal Effects: Low-Income Sample}

For the low-income subsample, the marginal effects of GDP on $\mathrm{CO}_{2}$ are, respectively $-1.0 \times 10^{10}(-1.910)$ for regimes 1(2) and suggest a smaller (larger) negative relationship between GDP and pollution (we use $\mathrm{CO}_{2}$ and pollution interchangeably) in regime 1(2). Furthermore, the marginal effects of adopting renewable energy policies on $\mathrm{CO}_{2}$ are $-1.0 \times 10^{10}(0.061)$ for regime $1(2)$, respectively. Hence, for low (high) GDP is associated with higher (lower) pollution (a V curve) and imply that adoption of renewable energy sources by low-income countries can decrease pollution. Finally, we present results on the impact of urbanization on pollution. The marginal effects of urbanization on $\mathrm{CO}_{2}$ are $-1.0 \times 10^{10}(-0.675)$ for regime $1(2)$, respectively, implying a weak negative relationship between urbanization and pollution for regime 1 , and a stronger negative relationship for regime 2. Clearly, urbanization hurts low-income countries in terms of pollution output.

Next, for the low-income subsample, the marginal effects of FDI on pollution are $1.0 \times 10^{10}(0.008)$ for regime $1(2)$. These positive slopes imply that increases in FDI increases pollution in low-income countries. Finally, for low-income countries with high environmental sustainability rating levels, the impacts of FDI on pollution are $1.0 \times 10^{10}$ $(-0.123)$ in regime 1(2), respectively, and suggest that for countries with high environmental sustainability ratings, FDI are positively correlated with pollution only if GDP is low. For high GDP countries, the FDI/pollution link is negative. Hence, countries with relatively higher incomes in this subsample can attract foreign direct investment net inflows if they possess high levels of environmental sustainability ratings while simultaneously reducing pollution. 


\subsection{Marginal Effects: Middle-Income Subsample}

For the middle-income subsample, three regimes (low, mid, high GDP) emerge from the tests. The marginal effects of GDP on pollution are $-0.099(-0.377,-0.249)$ for regime $1(2,3)$, respectively, and imply an inverse $S$ curve pattern with a relatively smaller negative slope in regime 1, a larger negative slope in regime 2 , followed by a smaller negative slop in regime 3. Similarly, the marginal effects of renewable energy on pollution are -0.007 $(0.004,-0.013)$ for regime $1(2,3)$, respectively, and suggest an inverse $\mathrm{N}$ curve pattern with a negative slope in regime 1 , a positive slope in regime 2 , followed by another negative slope in regime 3.

Next, the marginal effects of urbanization on pollution are $-0.237(-0.097,0.010)$ for regimes $1(2,3)$, respectively. These findings reveal a $/-/-/+/$ relationship-V curve pattern for the three regimes. In addition, for the middle-income subsample, the marginal effects of FDI on pollution are $0.007(-0.006,0.006)$ for regime $1(2,3)$. These findings suggest $\mathrm{a} /+/-/+/$ (a N curve) for the three regimes. Clearly, for the middle- income subsample, FDI are positively (negatively, positively) associated with pollution for low (middle, high) GDP countries. These countries must attempt to maintain a delicate balance between attracting FDI and reducing pollution while improving domestic GDP.

Third, the interaction term provides evidence on the marginal effects of FDI when countries enjoy high levels of environmental sustainability ratings. For this subsample with high ratings, the relationship between FDI and pollution is $0.088\left(0,1.0 \times 10^{7}\right)$ in regime $1(2,3)$, respectively. FDI and pollution are positively (unrelated, strongly positively) related for low (medium, high) GDP countries, and indicate a quandary for middle-income countries boasting a high environmental sustainability rating - they can attract FDI only at the cost of higher pollution.

\section{Discussion}

In this paper, we show that adding a key intervening variable (a proxy for usage of renewable energy sources in the host country, REC) not utilized in the literature examining the environmental Kuznets curve relationship and the pollution haven hypothesis, alters these relationships. In addition, and unlike extant literature, we examine the impact of local government environmental regulations and foreign direct investment net inflows by explicitly introducing an interaction term of foreign direct investment net inflows and an environmental sustainability ratings proxy. We present our major findings highlighting differences in findings with the extant literature.

For the environmental Kuznets curve, the literature documents an $\mathrm{N}$ curve for selected developing countries [53]; an inverted U curve relationship for developed countries [53]; an inverted U curve for 12 of 15 developed countries [54]; and an inverted U curve for 56 sample countries, including low, middle, and high-income countries [55]. Some researchers argue against the long run validity of the inverted U-shape environmental Kuznets curve [73]. In addition, empirical findings vary between countries and regions $[16,29,74,75]$. In contrast, our results indicate that this relationship is an inverse $S$ curve for the full sample and for each subsample, but at different subsample specific negative rates. Our findings suggest that the GDP $/ \mathrm{CO}_{2}$ relationship is also country economic development level specific.

Next, the literature documents a negative relationship between renewable energy adoption and $\mathrm{CO}_{2}$ in developed countries [1,13]. Others find no evidence of any such relationship for low and middle-income countries $[12,13]$. However, we provide evidence that the renewable energy adoption $/ \mathrm{CO}_{2}$ relationship is an inverse $\mathrm{N}$ curve for the full and the middle-income samples, but a V curve for the low-income sample and indicate that low-income countries can reduce pollution by adopting renewable energy sources. However, our results also suggest that pollution can increase even with renewable energy adoption in high-income sample countries.

Third, the literature presents inconclusive evidence on the validity of the pollution haven hypothesis. Some show a positive relationship [31-34,58], while others find evidence of a negative relationship [43-45]. Here, we find evidence of a complex relationship 
between the variables of interest: an $\mathrm{N}$ curve for the full and the middle-income samples, but a smaller (larger) positive FDI/pollution relationship in regime 1(2) in the low-income subsample. These results affirm the selective validity of the pollution haven hypothesis only for low-income sample countries.

Finally, and unlike the extant literature, we investigate the impact of environmental sustainability ratings on the FDI/pollution relationship with an interaction term. Our findings indicate that high levels of environmental sustainability ratings in countries with relatively high incomes in low-income countries can attract foreign direct investment net inflows while reducing pollution while middle-income countries with high environmental sustainability ratings can attract foreign direct investment net inflows only with a small increase in pollution output.

Clearly, our results differ from extant literature in several different ways. Here we provide a summary of our key findings and relate it to prior research. First, with respect to the pollution haven hypothesis, in addition to examining the $\mathrm{FDI} / \mathrm{CO}_{2}$ relationship, we add an intervening variable (environmental sustainability ratings) and find that this variable alters the well-established $\mathrm{FDI} / \mathrm{CO}_{2}$ relationships documented in the literature, for our sample of countries. These differences from extant literature have been documented earlier. In addition, in contrast to prior research, our findings potentially alter established policy prescriptions for governments. We show that governments can attract FDI while simultaneously reducing $\mathrm{CO}_{2}$ emissions. Moreover, governments that enhance their environmental sustainability ratings can signal a positive environmental climate to potential firms, which in turn allows host countries to attract needed pollution reducing FDI into the country.

\section{Conclusions}

The results from the full sample runs clearly demonstrate that GDP is negatively associated with $\mathrm{CO}_{2}$ in the inverse $\mathrm{S}$ form (small negative for regimes 1 and 3 , and large negative for regime 2). In addition, the renewable energy $/ \mathrm{CO}_{2}$ relationship is an inverse $\mathrm{N}$ curve (negative, regimes 1 and 3; positive regime 2). Next, urbanization affects $\mathrm{CO}_{2}$ in the form of a $\mathrm{V}$ curve (negative in regimes 1 and 2; positive in regime 3. The impact of FDI on $\mathrm{CO}_{2}$ is an $\mathrm{N}$ curve (positive regimes 1 and 3; negative in regime 2). Finally, relatively high-income full sample countries can increase FDI while reducing $\mathrm{CO}_{2}$ by strengthening their environmental sustainability ratings. Our findings differ from those reported in the literature under the environmental Kuznets curve and the pollution haven hypothesis.

When analyzing the results separately for low-income and middle-income sample countries, we found that the results selectively differ by sample country income levels. For the low-income subsample, higher levels of GDP reduce $\mathrm{CO}_{2}$, albeit at different rates. Next, the adoption of renewable energy reduces $\mathrm{CO}_{2}$ for low GDP countries but increases pollution for high GDP countries. Third, urbanization decreases pollution output for low and mid GDP countries but at different rates. Fourth, FDI into low-income countries cause pollution to increase as a function of GDP. Finally, low-income countries can take initiatives to enhance their environmental sustainability ratings since this move attracts foreign direct investment net inflows while reducing pollution output. Again, these findings differ from those reported under the environmental Kuznets curve hypothesis and the pollution haven hypothesis. One important finding is that we provide evidence that low-income countries can enhance their environmental sustainability ratings to attract foreign direct investment net inflows while reducing pollution output.

Our results for the middle-income countries are also selectively different from those observed for low-income countries. For the middle-income subsample, the relationship between GDP and pollution is an inverted S curve-higher levels of GDP reduces $\mathrm{CO}_{2}$, albeit at different rates. Next, the adoption of renewable energy reduces $\mathrm{CO}_{2}$ for low and high GDP but increases pollution for mid GDP (an inverted N curve). Third, urbanization decreases (increases) pollution output for low and mid (high) GDP countries (a V curve). Fourth, FDI into middle-income countries cause pollution to increase (decrease) for low 
and high (mid) GDP countries (an N curve). Fourth, we show that if middle-income countries enhance their environmental sustainability ratings, they can attract FDI while reducing pollution output. Finally, our findings suggest a quandary for high GDP middleincome countries enjoying high levels of environmental sustainability ratings-they can only attract FDI by allowing a slight increase in pollution. As argued earlier, these findings have not been reported in the literature.

We offer several policy implications and suggestions for further research. Practically, from a policy perspective, we suggest that existing prescriptions based on tests of the environmental Kuznets curve and the pollution hypotheses should also consider the impact of a country's GDP status on relationships of interest. Second, low- and middle-income countries should consider adopting (or strengthening existing) enforceable environmental sustainability ratings to attract FDI while reducing pollution output. Third, low-income countries should consider replacing traditional energy sources with renewable ones. Fourth, our findings suggest that renewable energy adoption for moderate growth GDP increases pollution output for both low-income and middle-income sample countries. Adoption of such resources for low and high-output sample countries can reduce pollution output. Therefore, countries at the mid end of the output spectrum should consider ambitious policies to reach higher output plateaus so that economic success comes with increased use of renewable energy resources while reducing overall pollution output-a desirable outcome. Next, urbanization policies reduce overall pollution output for mid-range and low-end GDP per capita output countries. However, urbanization at high GDP output should be discouraged since they lead to higher pollution output. For middle-income countries, they should attempt to reach high levels of output since this strategy is associated with lower pollution output. Attraction of FDI increases with high output but at a small pollution cost if countries enforce environmental sustainability policies.

For academics and practitioners, this research can be extended to other developed countries to examine whether the relationships examined here hold. The literature (and the results presented here) already document that the results are sample and time specific. Given these findings, researchers may find a different set of results using a different sample set and different time periods. Their work can enhance our knowledge of the relationships of interest as well as provide insights regarding the importance of renewable energy adoption in reducing $\mathrm{CO}_{2}$ locally and globally. Furthermore, since there is evidence that renewable energy costs have decreased substantially in recent years and that consumer interest on the environment and $\mathrm{CO}_{2}$ have increased, there is scope to address whether reduced renewable energy costs and increased stakeholder interest have motivated firms/countries to adopt these technologies. Research can also determine whether these adoptions have indeed reduced $\mathrm{CO}_{2}$. Finally, this paper only uses data spanning the years 2005 to 2014 (inclusive). Future research can extend the study to include more recent data as they become available. The addition of more countries can also determine whether the conclusions documented in this paper are robust.

The recent COVID-19 pandemic may also have structurally impacted the documented relationships. Given the game-changing nature of the pandemic, it is possible that global pollution may have decreased (due to decreased economic activity because of the pandemic) and that renewable energy adoption measures may have been postponed by domestic countries. Ample scope exists to address these issues.

From a theoretical perspective, research can also examine whether these relationships differ when oil producing vs. oil consuming countries are examined. Presumably, oilproducing countries may inhibit development of renewable energy resources since their economics are heavily dependent on carbon-based products. Finally, this research can be extended by identifying different types of renewable energy sources to determine the optimal path that simultaneously allows countries to develop economically, reduce pollution, and increase the income levels of its citizens.

As is typical, there are several limitations of this study. One key limitation (as documented earlier) is the limitations on data availability. Next, we do not consider explicitly 
the relative costs of adoption of renewable energy (vis a vis fossil fuel energy) in the modeling process. Arguably, this variable may alter our conclusions. Similarly, other factors documented in the literature as influencing the two key relationships (the environmental Kuznets curve and the pollution haven hypothesis) have not been introduced in our models, primarily because they further attenuate data for analysis. There is ample scope for researchers to address these limitations as more data become available.

Author Contributions: C.-H.W.: software, formal analysis, investigation, resources, data curation, visualization, and writing. P.P.: conceptualization, validation, writing - review and editing, and supervision. C.-H.H.: conceptualization, methodology, writing—original draft, and project administration. All authors have read and agreed to the published version of the manuscript.

Funding: This research received no external funding.

Institutional Review Board Statement: Not applicable since no human subjects were involved.

Informed Consent Statement: Not applicable.

Data Availability Statement: Data are available upon request.

Conflicts of Interest: The authors declare no conflict of interest.

\section{Appendix A}

Table A1. Descriptive statistics, middle-income, and low-income sample data; 2005-2014 (inclusive). Overall data and separately for low- and middle-income countries.

\begin{tabular}{|c|c|c|c|c|c|c|c|c|c|}
\hline & & $\mathrm{CO}_{2}$ & GDP & REC & URBAN & BRER & PIESR & TACR & FDI \\
\hline \multirow[t]{3}{*}{ Mean } & All & 0.476 & 6.999 & 56.128 & 1.146 & 3.274 & 3.162 & 2.895 & 17.479 \\
\hline & Low & 0.304 & 6.229 & 79.939 & 1.523 & 3.048 & 3.064 & 2.654 & 17.055 \\
\hline & Middle & 0.587 & 7.493 & 40.864 & 0.905 & 3.419 & 3.224 & 3.050 & 17.750 \\
\hline \multirow[t]{3}{*}{ Median } & All & 0.321 & 6.910 & 60.057 & 1.130 & 3.500 & 3.000 & 3.000 & 19.072 \\
\hline & Low & 0.261 & 6.223 & 83.808 & 1.277 & 3.000 & 3.000 & 2.500 & 18.753 \\
\hline & Middle & 0.388 & 7.382 & 43.829 & 0.767 & 3.500 & 3.500 & 3.000 & 19.306 \\
\hline \multirow[t]{3}{*}{ Maximum } & All & 4.495 & 9.056 & 97.422 & 4.541 & 4.500 & 4.500 & 4.500 & 22.983 \\
\hline & Low & 1.035 & 7.003 & 97.422 & 4.541 & 4.500 & 4.000 & 3.500 & 22.625 \\
\hline & Middle & 4.495 & 9.056 & 92.961 & 4.267 & 4.500 & 4.500 & 4.500 & 22.983 \\
\hline \multirow[t]{3}{*}{ Minimum } & All & 0.048 & 5.014 & 0.862 & -4.670 & 1.500 & 1.500 & 1.000 & -20.331 \\
\hline & Low & 0.048 & 5.014 & 40.467 & -0.550 & 1.500 & 2.000 & 1.000 & -20.331 \\
\hline & Middle & 0.080 & 5.821 & 0.862 & -4.670 & 2.500 & 1.500 & 1.500 & -20.065 \\
\hline \multirow[t]{3}{*}{ Std. Dev. } & All & 0.504 & 0.864 & 30.830 & 1.209 & 0.580 & 0.550 & 0.695 & 7.664 \\
\hline & Low & 0.206 & 0.407 & 14.705 & 1.089 & 0.594 & 0.541 & 0.575 & 7.752 \\
\hline & Middle & 0.599 & 0.703 & 28.722 & 1.221 & 0.521 & 0.548 & 0.722 & 7.605 \\
\hline \multirow[t]{3}{*}{ Skewness } & All & 4.045 & 0.424 & -0.484 & -0.462 & -0.051 & -0.347 & 0.241 & -4.050 \\
\hline & Low & 1.385 & -0.350 & -1.267 & 0.473 & -0.143 & -0.218 & -0.240 & -4.024 \\
\hline & Middle & 3.445 & 0.434 & 0.088 & -0.839 & 0.299 & -0.451 & 0.210 & -4.083 \\
\hline \multirow[t]{3}{*}{ Kurtosis } & All & 24.914 & 2.616 & 1.935 & 6.460 & 2.928 & 2.767 & 2.906 & 18.714 \\
\hline & Low & 4.665 & 2.846 & 3.561 & 2.985 & 2.493 & 2.155 & 2.515 & 18.418 \\
\hline & Middle & 17.742 & 2.504 & 1.839 & 7.526 & 2.660 & 3.238 & 2.623 & 18.988 \\
\hline \multirow[t]{3}{*}{$\mathrm{N}$} & All & 640 & 640 & 640 & 640 & 640 & 640 & 640 & 640 \\
\hline & Low & 250 & 250 & 250 & 250 & 250 & 250 & 250 & 250 \\
\hline & Middle & 390 & 390 & 390 & 390 & 390 & 390 & 390 & 390 \\
\hline
\end{tabular}


Table A2. (a) Sample middle-income and low-income countries. (b) Differences in sample means: middle and low-income countries.

(a) Sample middle-income and low-income countries

Low Income Countries

Benin, Burkina Faso, Burundi, Central African Republic, Chad, Comoros, Congo, Dem. Rep., Ethiopia, Gambia, Guinea,

Guinea-Bissau, Haiti, Madagascar, Malawi, Mali, Mozambique,

Nepal, Niger, Rwanda, Senegal, Sierra Leone, Tanzania, Togo, Uganda, Zimbabwe

\section{Middle Income Countries}

Bangladesh, Bhutan, Bolivia, Cabo Verde, Cambodia, Cameroon,

Congo, Rep., Djibouti, Dominica, Ghana, Grenada, Guyana,

Honduras, Kenya, Kiribati, Kyrgyz Republic, Lao PDR, Lesotho,

Maldives, Mauritania, Moldova, Mongolia, Nicaragua, Nigeria,

Pakistan, Papua New Guinea, Samoa, Solomon Islands, Sri

Lanka, St. Lucia, St. Vincent and the Grenadines, Sudan,

Tajikistan, Tonga, Uzbekistan, Vanuatu, Vietnam, Yemen, Rep., Zambia

(b) Differences in sample means: middle and low-income countries.

\begin{tabular}{cccc}
\hline Variable & Difference & $\boldsymbol{t}$ Value & Sig.2 (Tailed) \\
\hline $\mathrm{CO}_{2}$ & -0.283 & -7.192 & 0.000 \\
GDP & -1.264 & -25.780 & 0.000 \\
REC & 39.075 & 19.900 & 0.000 \\
URBAN & 0.618 & 6.513 & 0.000 \\
BRER & -0.371 & -8.317 & 0.000 \\
PIESR & -0.160 & -3.631 & 0.000 \\
TACR & -0.396 & -7.312 & 0.000 \\
FDI & -0.696 & -1.120 & 0.263 \\
\hline
\end{tabular}

Table A3. (a) Sample correlation estimates: overall sample. (b) Sample correlation estimates: low-income countries. (c) Sample correlation estimates: middle-income countries.

(a) Sample correlation estimates: overall sample

\begin{tabular}{|c|c|c|c|c|c|c|c|c|c|c|c|c|c|c|}
\hline \multicolumn{15}{|l|}{ Correlation } \\
\hline$t$-Statistic & $\mathrm{CO}_{2}$ & & GDP & & REC & & URBAN & & BRER & & PIESR & & TACR & FDI \\
\hline $\mathrm{CO}_{2}$ & 1 & & & & & & & & & & & & & \\
\hline GDP & $\begin{array}{l}0.100 \\
(2.54)\end{array}$ & $* *$ & $\begin{array}{c}1 \\
----\end{array}$ & & & & & & & & & & & \\
\hline REC & $\begin{array}{l}-0.464 \\
(-13.24)\end{array}$ & $* * *$ & $\begin{array}{l}-0.700 \\
(-24.78)\end{array}$ & $* * *$ & $\begin{array}{c}1 \\
----\end{array}$ & & & & & & & & & \\
\hline URBAN & $\begin{array}{l}-0.176 \\
(-4.51)\end{array}$ & $* * *$ & $\begin{array}{l}-0.344 \\
(-9.27)\end{array}$ & $* * *$ & $\begin{array}{c}0.414 \\
(11.49)\end{array}$ & $* * *$ & $\begin{array}{c}1 \\
----\end{array}$ & & & & & & & \\
\hline BRER & $\begin{array}{l}-0.028 \\
(-0.70)\end{array}$ & & $\begin{array}{c}0.421 \\
(11.73)\end{array}$ & $* * *$ & $\begin{array}{l}-0.318 \\
(-8.46)\end{array}$ & $* * *$ & $\begin{array}{l}0.003 \\
(0.07)\end{array}$ & & $\begin{array}{c}1 \\
----\end{array}$ & & & & & \\
\hline PIESR & $\begin{array}{l}0.035 \\
(0.87)\end{array}$ & & $\begin{array}{l}0.270 \\
(7.09)\end{array}$ & $* * *$ & $\begin{array}{l}-0.167 \\
(-4.27)\end{array}$ & $* * *$ & $\begin{array}{l}0.154 \\
(3.92)\end{array}$ & $* * *$ & $\begin{array}{l}0.576 \\
(17.79)\end{array}$ & $* * *$ & $\begin{array}{c}1 \\
----\end{array}$ & & & \\
\hline TACR & $\begin{array}{l}-0.152 \\
(-3.87)\end{array}$ & $* * *$ & $\begin{array}{c}0.517 \\
(15.27)\end{array}$ & $* * *$ & $\begin{array}{l}-0.325 \\
(-8.68)\end{array}$ & $* * *$ & $\begin{array}{l}-0.071 \\
(-1.80)\end{array}$ & $*$ & $\begin{array}{l}0.575 \\
(17.76)\end{array}$ & $* * *$ & $\begin{array}{l}0.506 \\
(14.83)\end{array}$ & $* * *$ & $\begin{array}{c}1 \\
-----\end{array}$ & \\
\hline FDI & $\begin{array}{l}0.062 \\
(1.57)\end{array}$ & & $\begin{array}{l}0.026 \\
(0.65)\end{array}$ & & $\begin{array}{l}0.092 \\
(2.33)\end{array}$ & $* *$ & $\begin{array}{l}0.084 \\
(2.13)\end{array}$ & $* *$ & $\begin{array}{l}0.149 \\
(3.81)\end{array}$ & $* * *$ & $\begin{array}{l}0.119 \\
(3.02)\end{array}$ & $* * *$ & $\begin{array}{l}-0.002 \\
(-0.05)\end{array}$ & $\begin{array}{r}1 \\
---\end{array}$ \\
\hline
\end{tabular}


Table A3. Cont.

(b) Sample correlation estimates: low-income countries.

\begin{tabular}{|c|c|c|c|c|c|c|c|c|c|c|c|c|c|c|}
\hline \multicolumn{15}{|l|}{ Correlation } \\
\hline$t$-Statistic & $\mathrm{CO}_{2}$ & & GDP & & REC & & URBAI & & BRER & & PIESR & & TACR & FDI \\
\hline $\mathrm{CO}_{2}$ & 1 & & & & & & & & & & & & & \\
\hline GDP & $\begin{array}{l}0.277 \\
(4.54)\end{array}$ & $* * *$ & 1 & & & & & & & & & & & \\
\hline REC & $\begin{array}{l}-0.525 \\
(-9.70)\end{array}$ & $* * *$ & $\begin{array}{l}-0.484 \\
(-8.70)\end{array}$ & $* * *$ & 1 & & & & & & & & & \\
\hline URBAN & $\begin{array}{l}-0.373 \\
(-6.33)\end{array}$ & $* * *$ & $\begin{array}{l}-0.147 \\
(-2.35)\end{array}$ & $* *$ & $\begin{array}{l}0.360 \\
(6.07)\end{array}$ & $* * *$ & 1 & & & & & & & \\
\hline BRER & $\begin{array}{l}-0.108 \\
(-1.71)\end{array}$ & * & $\begin{array}{l}0.130 \\
(2.06)\end{array}$ & $* *$ & $\begin{array}{l}-0.105 \\
(-1.66)\end{array}$ & * & $\begin{array}{l}0.434 \\
(7.59)\end{array}$ & $* * *$ & 1 & & & & & \\
\hline PIESR & $\begin{array}{l}-0.078 \\
(-1.23)\end{array}$ & & $\begin{array}{l}0.077 \\
(1.22)\end{array}$ & & $\begin{array}{l}-0.043 \\
(-0.69)\end{array}$ & & $\begin{array}{l}0.352 \\
(5.92)\end{array}$ & $* * *$ & $\begin{array}{l}0.733 \\
(16.98)\end{array}$ & $* * *$ & 1 & & & \\
\hline TACR & $\begin{array}{l}-0.216 \\
(-3.48)\end{array}$ & $* * *$ & $\begin{array}{l}0.158 \\
(2.51)\end{array}$ & $* *$ & $\begin{array}{l}-0.097 \\
(-1.53)\end{array}$ & & $\begin{array}{l}0.369 \\
(6.26)\end{array}$ & $* * *$ & $\begin{array}{l}0.645 \\
(13.30)\end{array}$ & $* * *$ & $\begin{array}{l}0.600 \\
(11.82)\end{array}$ & $* * *$ & 1 & \\
\hline FDI & $\begin{array}{l}0.059 \\
(0.93)\end{array}$ & & $\begin{array}{l}-0.008 \\
(-0.13)\end{array}$ & & $\begin{array}{l}0.029 \\
(0.45)\end{array}$ & & $\begin{array}{l}0.123 \\
(1.95)\end{array}$ & $*$ & $\begin{array}{l}0.103 \\
(1.64)\end{array}$ & & $\begin{array}{l}0.114 \\
(1.81)\end{array}$ & * & $\begin{array}{l}0.042 \\
(0.67)\end{array}$ & 1 \\
\hline
\end{tabular}

(c) Sample correlation estimates: middle-income countries.

\begin{tabular}{|c|c|c|c|c|c|c|c|c|c|c|c|c|c|c|}
\hline \multicolumn{15}{|l|}{ Correlation } \\
\hline$t$-Statistic & $\mathrm{CO}_{2}$ & & GDP & & REC & & URBAN & & BRER & & PIESR & & TACR & FDI \\
\hline $\mathrm{CO}_{2}$ & 1 & & & & & & & & & & & & & \\
\hline GDP & $\begin{array}{l}-0.198 \\
(-3.97)\end{array}$ & $* * *$ & 1 & & & & & & & & & & & \\
\hline REC & $\begin{array}{l}-0.378 \\
(-8.05)\end{array}$ & $* * *$ & $\begin{array}{l}-0.468 \\
(-10.43)\end{array}$ & $* * *$ & 1 & & & & & & & & & \\
\hline URBAN & $\begin{array}{l}-0.073 \\
(-1.45)\end{array}$ & & $\begin{array}{l}-0.283 \\
(-5.82)\end{array}$ & $* * *$ & $\begin{array}{l}0.348 \\
(7.31)\end{array}$ & $* * *$ & 1 & & & & & & & \\
\hline BRER & $\begin{array}{l}-0.147 \\
(-2.93)\end{array}$ & $* * *$ & $\begin{array}{l}0.389 \\
(8.32)\end{array}$ & $* * *$ & $\begin{array}{l}-0.204 \\
(-4.10)\end{array}$ & $* * *$ & $\begin{array}{l}-0.137 \\
(-2.72)\end{array}$ & $* * *$ & 1 & & & & & \\
\hline PIESR & $\begin{array}{l}0.011 \\
(0.21)\end{array}$ & & $\begin{array}{l}0.314 \\
(6.51)\end{array}$ & $* * *$ & $\begin{array}{l}-0.125 \\
(-2.48)\end{array}$ & $* *$ & $\begin{array}{l}0.110 \\
(2.19)\end{array}$ & $* *$ & $\begin{array}{l}0.446 \\
(9.83)\end{array}$ & $* * *$ & 1 & & & \\
\hline TACR & $\begin{array}{l}-0.265 \\
(-5.42)\end{array}$ & $* * *$ & $\begin{array}{c}0.573 \\
(13.78)\end{array}$ & $* * *$ & $\begin{array}{l}-0.234 \\
(-4.75)\end{array}$ & $* * *$ & $\begin{array}{l}-0.170 \\
(-3.41)\end{array}$ & $* * *$ & $\begin{array}{l}0.484 \\
(10.89)\end{array}$ & $* * *$ & $\begin{array}{l}0.440 \\
(9.64)\end{array}$ & $* * *$ & 1 & \\
\hline FDI & $\begin{array}{l}0.056 \\
(1.11)\end{array}$ & & $\begin{array}{l}-0.009 \\
(-0.18)\end{array}$ & & $\begin{array}{l}0.202 \\
(4.07)\end{array}$ & $* * *$ & $\begin{array}{l}0.084 \\
(1.66)\end{array}$ & * & $\begin{array}{l}0.172 \\
(3.44)\end{array}$ & $* * *$ & $\begin{array}{l}0.114 \\
(2.25)\end{array}$ & $* *$ & $\begin{array}{l}-0.045 \\
(0.88)\end{array}$ & 1 \\
\hline
\end{tabular}

Notes: ${ }^{* * *}, * *$ and ${ }^{*}$ denote statistical significance at the $1 \%, 5 \%$, and $10 \%$ levels, respectively. Corresponding t-values in parentheses.

Table A4. Cross-sectional dependence tests.

\begin{tabular}{|c|c|c|c|c|c|c|}
\hline Test & Full Sample & & $\begin{array}{l}\text { Low Income } \\
\text { Sample }\end{array}$ & & Middle Income Sample & \\
\hline Breusch-Pagan LM & $\begin{array}{c}3572.75 \\
(0.00)\end{array}$ & $* * *$ & $\begin{array}{c}545.78 \\
(0.00)\end{array}$ & $* * *$ & $\begin{array}{c}1918.07 \\
(0.00)\end{array}$ & $* * *$ \\
\hline Pesaran scaled LM & $\begin{array}{l}24.52 \\
(0.00)\end{array}$ & $* * *$ & $\begin{array}{l}10.03 \\
(0.00)\end{array}$ & $* * *$ & $\begin{array}{l}30.58 \\
(0.00)\end{array}$ & $* * *$ \\
\hline Pesaran CD & $\begin{array}{l}1.89 \\
(0.06)\end{array}$ & * & $\begin{array}{c}2.12 \\
(0.03)\end{array}$ & $* *$ & $\begin{array}{l}13.52 \\
(0.00)\end{array}$ & $* * *$ \\
\hline
\end{tabular}

Notes: Null hypothesis: No cross-section dependence (correlation). ${ }^{* * *}, * *$, and ${ }^{*}$ denote statistical significance at the $1 \%, 5 \%$, and $10 \%$ levels, respectively. $p$-values reported in parentheses. 
Table A5. Panel unit root test across sample variables. Null: Unit root (assumes common unit root process).

\begin{tabular}{|c|c|c|c|c|c|c|c|c|c|c|c|c|c|c|c|}
\hline & $\mathrm{CO}_{2}$ & & GDP & & REC & & URBAN & & BRER & & PIESR & & TACR & FDI & \\
\hline $\begin{array}{l}\text { Levin, Lin } \\
\& \text { Chu t* }\end{array}$ & $\begin{array}{c}-6.199 \\
(0.00)\end{array}$ & $* * *$ & $\begin{array}{c}-10.835 \\
(0.00)\end{array}$ & $* * *$ & $\begin{array}{l}-20.602 \\
(0.00)\end{array}$ & $* * *$ & $\begin{array}{l}-16.725 \\
(0.00)\end{array}$ & $* * *$ & $\begin{array}{c}-11.116 \\
(0.00)\end{array}$ & $* * *$ & $\begin{array}{l}-6.158 \\
(0.00)\end{array}$ & $* * *$ & $\begin{array}{l}-4.053 \\
(0.00)\end{array}$ & $\begin{array}{c}* * * 32.264 \\
(0.00)\end{array}$ & $* * *$ \\
\hline
\end{tabular}

Notes: ${ }^{* * *}$ denotes statistical significance at the $1 \%$ level. The corresponding $p$-values are reported in parentheses.

Table A6. Homogeneity tests (linearity tests).

\begin{tabular}{|c|c|c|c|c|c|c|}
\hline Statistics & Full Sample & & $\begin{array}{l}\text { Low Income } \\
\text { Sample }\end{array}$ & & $\begin{array}{c}\text { Middle Income } \\
\text { Sample }\end{array}$ & \\
\hline $\begin{array}{c}\mathrm{H}_{0} \text { : Linear model } \\
\mathrm{H}_{1} \text { : PSTR model with at least on } \\
\text { variable } \mathrm{r}=1\end{array}$ & & & & & & \\
\hline Wald tests (LM) & $\begin{array}{c}189.196 \\
(0.00)\end{array}$ & $* * *$ & $\begin{array}{c}52.472 \\
(0.00)\end{array}$ & $* * *$ & $\begin{array}{c}160.496 \\
(0.00)\end{array}$ & $* * *$ \\
\hline Fisher tests (LMF) & $\begin{array}{l}11.092 \\
(0.00)\end{array}$ & $* * *$ & $\begin{array}{l}2.581 \\
(0.00)\end{array}$ & $* * *$ & $\begin{array}{l}10.989 \\
(0.00)\end{array}$ & $* * *$ \\
\hline LRT tests (LRT) & $\begin{array}{c}224.279 \\
(0.00)\end{array}$ & $* * *$ & $\begin{array}{c}58.895 \\
(0.00)\end{array}$ & $* * *$ & $\begin{array}{c}206.788 \\
(0.00)\end{array}$ & $* * *$ \\
\hline
\end{tabular}

Notes: ${ }^{* * *}$ denotes statistical significance at the $1 \%$, level. $p$-values reported in parentheses.

Table A7. Model tests: number of location parameters (m).

\begin{tabular}{|c|c|c|c|c|c|c|}
\hline & Full Sample & & $\begin{array}{l}\text { Low Income } \\
\text { Sample }\end{array}$ & & $\begin{array}{l}\text { Middle Income } \\
\text { Sample }\end{array}$ & \\
\hline \multicolumn{7}{|c|}{$\begin{array}{l}\text { Select } \mathrm{m}=2 \text { if the rejection of } \mathrm{H}_{02} \text { is the strongest one, otherwise } \\
\text { select } \mathrm{m}=1 .\end{array}$} \\
\hline $\mathrm{H}_{03}: \beta_{3}=0$ & $\begin{array}{r}2.789 \\
(0.00)\end{array}$ & $* * *$ & $\begin{array}{l}0.432 \\
(0.99)\end{array}$ & & $\begin{array}{l}1.158 \\
(0.29)\end{array}$ & \\
\hline $\mathrm{H}_{02}: \beta_{2}=0 \mid \beta_{3}=0$ & $\begin{array}{l}2.861 \\
(0.00)\end{array}$ & $* * *$ & $\begin{array}{l}0.464 \\
(0.98)\end{array}$ & & $\begin{array}{l}2.660 \\
(0.00)\end{array}$ & $* * *$ \\
\hline $\mathrm{H}_{01}: \beta_{1}=0 \mid \beta_{2}=\beta_{3}=0$ & $\begin{array}{l}4.339 \\
(0.00)\end{array}$ & $* * *$ & $\begin{array}{l}1.644 \\
(0.04)\end{array}$ & ** & $\begin{array}{l}5.859 \\
(0.00)\end{array}$ & $* * *$ \\
\hline Final model is $\mathrm{m}$ & 1 & & 1 & & 1 & \\
\hline
\end{tabular}

Note: ${ }^{* * *}$, and ${ }^{* *}$ denote statistical significance at the $1 \%$ and $5 \%$ levels, respectively. $p$-values reported in parentheses.

Table A8. Test results, no remaining heterogeneity.

\begin{tabular}{|c|c|c|c|c|c|}
\hline & Full Sample & & $\begin{array}{l}\text { Low Income } \\
\text { Sample }\end{array}$ & $\begin{array}{l}\text { Middle Income } \\
\text { Sample }\end{array}$ & \\
\hline Estimation of the model with $\mathrm{r}(\mathrm{m})$ & $2(1)$ & & $1(1)$ & $2(1)$ & \\
\hline RSS & 7.766 & & 0.527 & 6.250 & \\
\hline RSS under $\mathrm{H}_{1}$ & 7.564 & & 0.543 & 5.966 & \\
\hline \multicolumn{6}{|c|}{$\mathrm{H}_{0}$ : PSTR with $\mathrm{r}=1 ; \mathrm{H}_{1}$ : PSTR with at least $\mathrm{r}=2$} \\
\hline Wald tests (LM) & $\begin{array}{c}57.089 \\
(0.00)\end{array}$ & $* * *$ & $\begin{array}{c}-7.769 \\
(1.00)\end{array}$ & $\begin{array}{c}25.182 \\
(0.00)\end{array}$ & *** \\
\hline Fisher tests (LMF) & $\begin{array}{l}7.765 \\
(0.00)\end{array}$ & $* * *$ & $\begin{array}{c}-0.878 \\
(1.00)\end{array}$ & $\begin{array}{l}3.254 \\
(0.00)\end{array}$ & $* * *$ \\
\hline LRT tests (LRT) & $\begin{array}{l}59.798 \\
(0.00)\end{array}$ & $* * *$ & $\begin{array}{c}-7.650 \\
(1.00)\end{array}$ & $\begin{array}{c}26.032 \\
(0.00)\end{array}$ & *** \\
\hline \multicolumn{6}{|c|}{$\mathrm{H}_{0}:$ PSTR with $\mathrm{r}=2 ; \mathrm{H}_{1}:$ PSTR with at least $\mathrm{r}=3$} \\
\hline Wald tests (LM) & $\begin{array}{c}16.649 \\
(0.02)\end{array}$ & $* * *$ & & $\begin{array}{c}17.723 \\
(0.01)\end{array}$ & ** \\
\hline Fisher tests (LMF) & $\begin{array}{l}2.091 \\
(0.04)\end{array}$ & $* *$ & & $\begin{array}{l}2.197 \\
(0.03)\end{array}$ & ** \\
\hline LRT tests (LRT) & $\begin{array}{l}16.870 \\
(0.02)\end{array}$ & ** & & $\begin{array}{l}18.138 \\
(0.01)\end{array}$ & ** \\
\hline
\end{tabular}


Table A9. PSTR model parameter estimation results: full sample and subsamples.

\begin{tabular}{|c|c|c|c|c|c|c|c|c|c|c|c|c|}
\hline \multirow[b]{2}{*}{ Variable } & \multicolumn{4}{|c|}{ Full Sample } & \multicolumn{3}{|c|}{ Low Income Sample } & \multicolumn{5}{|c|}{ Middle Income Sample } \\
\hline & (1) & & (2) & & (1) & & (2) & & (1) & & (2) & \\
\hline $\mathrm{GDP}_{1}$ & $\begin{array}{c}-0.045 \\
(0.04)\end{array}$ & & $\begin{array}{c}-0.079 \\
(0.04)\end{array}$ & $* *$ & $\begin{array}{l}-1.0 \times 10^{10} \\
\left(1.0 \times 10^{10}\right)\end{array}$ & $* * *$ & $\begin{array}{l}-1.0 \times 10^{10} \\
\left(1.0 \times 10^{9}\right)\end{array}$ & $* * *$ & $\begin{array}{c}-0.099 \\
(0.17)\end{array}$ & & $\begin{array}{l}2.121 \\
(1.17)\end{array}$ & * \\
\hline $\mathrm{REC}_{1}$ & $\begin{array}{c}-0.009 \\
(0.00)\end{array}$ & $* * *$ & $\begin{array}{c}-0.009 \\
(0.00)\end{array}$ & $* * *$ & $\begin{array}{l}-1.0 \times 10^{10} \\
\left(1.0 \times 10^{10}\right)\end{array}$ & $* * *$ & $\begin{array}{c}-1.0 \times 10^{10} \\
\left(1.0 \times 10^{9}\right)\end{array}$ & $* * *$ & $\begin{array}{c}-0.007 \\
(0.00)\end{array}$ & $* *$ & $\begin{array}{c}-0.020 \\
(0.01)\end{array}$ & $* * *$ \\
\hline $\mathrm{URBAN}_{1}$ & $\begin{array}{c}-0.095 \\
(0.03)\end{array}$ & $* * *$ & $\begin{array}{c}-0.041 \\
(0.02)\end{array}$ & * & $\begin{array}{l}-1.0 \times 10^{10} \\
\left(1.0 \times 10^{10}\right)\end{array}$ & & $\begin{array}{c}-1.0 \times 10^{10} \\
\left(1.0 \times 10^{9}\right)\end{array}$ & & $\begin{array}{c}-0.237 \\
(0.06)\end{array}$ & $* * *$ & $\begin{array}{c}-0.259 \\
(0.14)\end{array}$ & * \\
\hline $\mathrm{BRER}_{1}$ & $\begin{array}{c}-0.125 \\
(0.03)\end{array}$ & $* * *$ & $\begin{array}{c}-0.106 \\
(0.03)\end{array}$ & $* * *$ & $\begin{array}{l}-1.0 \times 10^{10} \\
\left(1.0 \times 10^{10}\right)\end{array}$ & & $\begin{array}{l}-1.0 \times 10^{10} \\
\left(1.0 \times 10^{9}\right)\end{array}$ & & $\begin{array}{c}-0.411 \\
(0.10)\end{array}$ & $* * *$ & $\begin{array}{c}-0.689 \\
(0.04)\end{array}$ & $* * *$ \\
\hline $\mathrm{PIESR}_{1}$ & $\begin{array}{l}0.072 \\
(0.03)\end{array}$ & $* *$ & $\begin{array}{l}0.034 \\
(0.02)\end{array}$ & & $\begin{array}{l}-1.0 \times 10^{10} \\
\left(1.0 \times 10^{10}\right)\end{array}$ & & $\begin{array}{c}-1.0 \times 10^{10} \\
\left(1.0 \times 10^{9}\right)\end{array}$ & & $\begin{array}{l}0.263 \\
(0.08)\end{array}$ & $* * *$ & $\begin{array}{c}-0.005 \\
\left(1.0 \times 10^{7}\right)\end{array}$ & $* * *$ \\
\hline $\mathrm{TACR}_{1}$ & $\begin{array}{c}-0.088 \\
(0.03)\end{array}$ & $* * *$ & $\begin{array}{c}-0.092 \\
(0.03)\end{array}$ & $* * *$ & $\begin{array}{l}-1.0 \times 10^{10} \\
\left(1.0 \times 10^{10}\right)\end{array}$ & & $\begin{array}{l}1.0 \times 10^{10} \\
\left(1.0 \times 10^{9}\right)\end{array}$ & & $\begin{array}{c}-0.334 \\
(0.09)\end{array}$ & $* * *$ & $\begin{array}{c}-1.104 \\
\left(1.0 \times 10^{7}\right)\end{array}$ & $* * *$ \\
\hline $\mathrm{FDI}_{1}$ & $\begin{array}{l}0.002 \\
(0.00)\end{array}$ & ** & $\begin{array}{l}-0.00 \\
(0.00)\end{array}$ & $* *$ & $\begin{array}{c}1.0 \times 10^{10} \\
\left(1.0 \times 10^{10}\right)\end{array}$ & & $\begin{array}{c}-1.0 \times 10^{10} \\
\left(1.0 \times 10^{9}\right)\end{array}$ & & $\begin{array}{l}0.007 \\
(0.00)\end{array}$ & $* *$ & $\begin{array}{c}0.011 \\
\left(1.0 \times 10^{7}\right)\end{array}$ & $* * *$ \\
\hline $\mathrm{DPIESR}_{1}{ }^{*} \mathrm{FDI}_{1}$ & & & $\begin{array}{l}0.005 \\
(0.00)\end{array}$ & $* * *$ & & & $\begin{array}{l}1.0 \times 10^{10} \\
\left(1.0 \times 10^{9}\right)\end{array}$ & $* * *$ & & & $\begin{array}{c}0.088 \\
\left(1.0 \times 10^{7}\right) \\
\end{array}$ & $* * *$ \\
\hline $\mathrm{GDP}_{2}$ & $\begin{array}{c}-0.192 \\
(0.05)\end{array}$ & $* * *$ & $\begin{array}{c}-62.593 \\
(27.53)\end{array}$ & $* *$ & $\begin{array}{c}-1.910 \\
(0.73)\end{array}$ & $* * *$ & $\begin{array}{c}-1.943 \\
(4.02)\end{array}$ & $* * *$ & $\begin{array}{c}-0.278 \\
(0.07)\end{array}$ & $* * *$ & $\begin{array}{c}-2.121 \\
(1.32)\end{array}$ & \\
\hline $\mathrm{REC}_{2}$ & $\begin{array}{l}0.013 \\
(0.00)\end{array}$ & $* * *$ & $\begin{array}{c}-3.492 \\
(0.89)\end{array}$ & $* * *$ & $\begin{array}{l}0.061 \\
(0.03)\end{array}$ & * & $\begin{array}{l}0.052 \\
(0.16)\end{array}$ & $* * *$ & $\begin{array}{l}0.011 \\
(0.00)\end{array}$ & $* * *$ & $\begin{array}{l}0.020 \\
(0.01)\end{array}$ & $* * *$ \\
\hline $\mathrm{URBAN}_{2}$ & $\begin{array}{l}0.094 \\
(0.06)\end{array}$ & & $\begin{array}{c}-24.578 \\
(8.76)\end{array}$ & $* * *$ & $\begin{array}{c}-0.675 \\
(0.73)\end{array}$ & & $\begin{array}{c}-0.573 \\
(4.00)\end{array}$ & & $\begin{array}{l}0.140 \\
(0.07)\end{array}$ & $* *$ & $\begin{array}{l}0.259 \\
(0.13)\end{array}$ & * \\
\hline $\mathrm{BRER}_{2}$ & $\begin{array}{l}0.177 \\
(0.07)\end{array}$ & $* *$ & $\begin{array}{c}-39.872 \\
(14.17)\end{array}$ & $* * *$ & $\begin{array}{l}0.271 \\
(0.81)\end{array}$ & & $\begin{array}{l}1.294 \\
(6.27)\end{array}$ & $* *$ & $\begin{array}{l}0.567 \\
(0.16)\end{array}$ & $* * *$ & $\begin{array}{l}0.689 \\
(0.03)\end{array}$ & $* * *$ \\
\hline $\mathrm{PIESR}_{2}$ & $\begin{array}{c}-0.479 \\
(0.11)\end{array}$ & $* * *$ & $\begin{array}{c}151.992 \\
(49.06)\end{array}$ & $* * *$ & $\begin{array}{l}0.435 \\
(0.77)\end{array}$ & & $\begin{array}{l}0.848 \\
(6.41)\end{array}$ & & $\begin{array}{c}-0.723 \\
(0.15)\end{array}$ & $* * *$ & $\begin{array}{c}0.005 \\
\left(1.0 \times 10^{7}\right)\end{array}$ & $* * *$ \\
\hline $\mathrm{TACR}_{2}$ & $\begin{array}{l}0.549 \\
(0.11)\end{array}$ & $* * *$ & $\begin{array}{c}-23.915 \\
(24.03)\end{array}$ & & $\begin{array}{l}2.873 \\
(1.05)\end{array}$ & $* * *$ & $\begin{array}{l}1.760 \\
(3.82)\end{array}$ & $* * *$ & $\begin{array}{l}0.687 \\
(0.13)\end{array}$ & $* * *$ & $\begin{array}{c}1.104 \\
\left(1.0 \times 10^{7}\right)\end{array}$ & $* * *$ \\
\hline $\mathrm{FDI}_{2}$ & $\begin{array}{c}-0.009 \\
(0.00)\end{array}$ & $* *$ & $\begin{array}{c}24.353 \\
(5.53)\end{array}$ & $* * *$ & $\begin{array}{l}0.008 \\
(0.02)\end{array}$ & & $\begin{array}{l}0.028 \\
(0.07)\end{array}$ & $* * *$ & $\begin{array}{c}-0.013 \\
(0.01)\end{array}$ & $* *$ & $\begin{array}{c}-0.011 \\
(0.00)\end{array}$ & $* * *$ \\
\hline $\mathrm{DPIESR}_{2} * \mathrm{FDI}_{2}$ & & & $\begin{array}{c}-5.370 \\
(3.35) \\
\end{array}$ & & & & $\begin{array}{c}-0.123 \\
(0.39)\end{array}$ & $* * *$ & & & $\begin{array}{c}-0.088 \\
\left(1.0 \times 10^{7}\right) \\
\end{array}$ & $* * *$ \\
\hline $\mathrm{GDP}_{3}$ & $\begin{array}{l}0.083 \\
(0.04)\end{array}$ & * & $\begin{array}{l}0.400 \\
(0.08)\end{array}$ & $* * *$ & & & & & $\begin{array}{l}0.128 \\
(0.05)\end{array}$ & $* * *$ & $\begin{array}{c}1.0 \times 10^{7} \\
\left(1.0 \times 10^{7}\right)\end{array}$ & \\
\hline $\mathrm{REC}_{3}$ & $\begin{array}{c}-0.018 \\
(0.00)\end{array}$ & $* * *$ & $\begin{array}{c}-0.004 \\
(0.00)\end{array}$ & $* *$ & & & & & $\begin{array}{c}-0.017 \\
(0.00)\end{array}$ & $* * *$ & $\begin{array}{l}-1.0 \times 10^{7} \\
\left(1.0 \times 10^{7}\right)\end{array}$ & \\
\hline $\mathrm{URBAN}_{3}$ & $\begin{array}{l}0.014 \\
(0.06)\end{array}$ & & $\begin{array}{l}0.030 \\
(0.04)\end{array}$ & & & & & & $\begin{array}{l}0.108 \\
(0.07)\end{array}$ & & $\begin{array}{c}1.0 \times 10^{7} \\
\left(1.0 \times 10^{7}\right)\end{array}$ & \\
\hline $\mathrm{BRER}_{3}$ & 0.055 & & 0.006 & & & & & & -0.092 & & $1.0 \times 10^{7}$ & \\
\hline & $(0.09)$ & & $(0.07)$ & & & & & & $(0.11)$ & & $\left(1.0 \times 10^{7}\right)$ & \\
\hline $\mathrm{PIESR}_{3}$ & $\begin{array}{l}0.677 \\
(0.15)\end{array}$ & $* * *$ & $\begin{array}{l}0.096 \\
(0.13)\end{array}$ & & & & & & $\begin{array}{l}0.672 \\
(0.14)\end{array}$ & $* * *$ & $\begin{array}{c}1.0 \times 10^{7} \\
\left(1.0 \times 10^{7}\right)\end{array}$ & $* *$ \\
\hline $\mathrm{TACR}_{3}$ & $\begin{array}{c}-0.664 \\
(0.14)\end{array}$ & $* * *$ & $\begin{array}{c}-0.621 \\
(0.14)\end{array}$ & $* * *$ & & & & & $\begin{array}{l}-0.620 \\
(0.13)\end{array}$ & $* * *$ & $\begin{array}{l}-1.0 \times 10^{7} \\
\left(1.0 \times 10^{7}\right)\end{array}$ & $* * *$ \\
\hline $\mathrm{FDI}_{3}$ & $\begin{array}{l}0.014 \\
(0.01)\end{array}$ & * & $\begin{array}{c}-0.074 \\
(0.02)\end{array}$ & $* * *$ & & & & & $\begin{array}{l}0.012 \\
(0.01)\end{array}$ & & $\begin{array}{c}1.0 \times 10^{7} \\
\left(1.0 \times 10^{7}\right)\end{array}$ & \\
\hline $\mathrm{DPIESR}_{3}{ }^{*} \mathrm{FDI}_{3}$ & & & $\begin{array}{l}0.030 \\
(0.01)\end{array}$ & $* * *$ & & & & & & & $\begin{array}{c}1.0 \times 10^{7} \\
\left(1.0 \times 10^{7}\right)\end{array}$ & $* * *$ \\
\hline
\end{tabular}


Table A9. Cont.

\begin{tabular}{|c|c|c|c|c|c|c|c|}
\hline \multirow[b]{2}{*}{ Variable } & \multicolumn{3}{|c|}{ Full Sample } & \multicolumn{2}{|c|}{ Low Income Sample } & \multicolumn{2}{|c|}{ Middle Income Sample } \\
\hline & (1) & (2) & & (1) & (2) & (1) & (2) \\
\hline $\mathrm{GDP}_{4}$ & & $\begin{array}{l}61.266 \\
(27.18)\end{array}$ & $* *$ & & & & \\
\hline $\mathrm{REC}_{4}$ & & $\begin{array}{l}3.468 \\
(0.88)\end{array}$ & $* * *$ & & & & \\
\hline $\mathrm{URBAN}_{4}$ & & $\begin{array}{c}24.542 \\
(8.73)\end{array}$ & $* * *$ & & & & \\
\hline $\mathrm{BRER}_{4}$ & & $\begin{array}{l}39.707 \\
(14.07)\end{array}$ & $* * *$ & & & & \\
\hline $\mathrm{PIESR}_{4}$ & & $\begin{array}{c}-150.683 \\
(48.46)\end{array}$ & $* * *$ & & & & \\
\hline $\mathrm{TACR}_{4}$ & & $\begin{array}{l}24.772 \\
(23.79)\end{array}$ & & & & & \\
\hline $\mathrm{FDI}_{4}$ & & $\begin{array}{c}-24.016 \\
(5.45)\end{array}$ & $* * *$ & & & & \\
\hline $\mathrm{DPIESR}_{4}{ }^{*} \mathrm{FDI}_{4}$ & & $\begin{array}{l}5.258 \\
(3.31)\end{array}$ & & & & & \\
\hline $\begin{array}{c}\text { Location } \\
\text { parameters }\end{array}$ & $7.26,7.87$ & $\begin{array}{c}7.73 \\
7.79,7.80\end{array}$ & & 6.21 & 6.21 & $\begin{array}{l}7.08 \\
7.92\end{array}$ & $7.71,7.86$ \\
\hline $\begin{array}{c}\text { Slope } \\
\text { parameters }\end{array}$ & 3.38 & $2.10,2.11$ & & 3.35 & 7.75 & 6.83 & 12.43 \\
\hline RSS & 7.77 & 6.64 & & 0.53 & 0.51 & 6.25 & 5.41 \\
\hline $\mathrm{r}(\mathrm{m})$ & $2(1)$ & $3(1)$ & & $1(1)$ & $1(1)$ & $2(1)$ & $2(1)$ \\
\hline
\end{tabular}

Notes: Standard errors in parentheses. ${ }^{* *}, * *$, and ${ }^{*}$ denote statistical significance at the $1 \%, 5 \%$, and $10 \%$ levels, respectively.

Table A10. Marginal effects: Full sample, low-income, and middle-income subsamples.

\begin{tabular}{|c|c|c|c|c|c|c|c|}
\hline & \multicolumn{3}{|c|}{ Without Interaction Term } & \multicolumn{4}{|c|}{ With Interaction Term } \\
\hline A. Full Sample & 1st regime & 2nd regime & 3rd regime & 1st regime & 2nd regime & 3rd regime & 4th regime \\
\hline Transition Value & 7.26 & 7.87 & & 7.73 & 7.79 & 7.80 & \\
\hline GDP & -0.045 & -0.237 & -0.153 & -0.079 & -62.672 & -62.272 & -1.006 \\
\hline REC & -0.009 & 0.004 & -0.014 & -0.009 & -3.501 & -3.505 & -0.037 \\
\hline URBAN & -0.095 & -0.001 & 0.012 & -0.041 & -24.618 & -24.588 & -0.047 \\
\hline BRER & -0.125 & 0.052 & 0.107 & -0.106 & -39.978 & -39.972 & -0.265 \\
\hline PIESR & 0.072 & -0.407 & 0.270 & 0.034 & 152.026 & 152.122 & 1.439 \\
\hline TACR & -0.088 & 0.462 & -0.202 & -0.092 & -24.007 & -24.628 & 0.144 \\
\hline FDI & 0.002 & -0.007 & 0.007 & -0.003 & 24.349 & 24.275 & 0.259 \\
\hline DPIESR * FDI & & & & 0.005 & -5.365 & -5.336 & -0.078 \\
\hline $\begin{array}{l}\text { B. Low income countries } \\
\text { Transition Value }\end{array}$ & $\begin{array}{c}\text { 1st regime } \\
6.21\end{array}$ & 2nd regime & & $\begin{array}{l}\text { 1st regime } \\
\quad 6.21\end{array}$ & 2nd regime & & \\
\hline GDP & $-1.0 \times 10^{10}$ & -1.910 & & $-1.0 \times 10^{10}$ & -1.943 & & \\
\hline REC & $-1.0 \times 10^{10}$ & 0.061 & & $-1.0 \times 10^{10}$ & 0.052 & & \\
\hline URBAN & $-1.0 \times 10^{10}$ & -0.675 & & $-1.0 \times 10^{10}$ & -0.573 & & \\
\hline BRER & $-1.0 \times 10^{10}$ & 0.271 & & $-1.0 \times 10^{10}$ & 1.294 & & \\
\hline PIESR & $-1.0 \times 10^{10}$ & 0.435 & & $-1.0 \times 10^{10}$ & 0.848 & & \\
\hline TACR & $-1.0 \times 10^{10}$ & 2.873 & & $1.0 \times 10^{10}$ & 1.760 & & \\
\hline FDI & $1.0 \times 10^{10}$ & 0.008 & & $-1.0 \times 10^{10}$ & 0.028 & & \\
\hline DPIESR * FDI & & & & $1.0 \times 10^{10}$ & -0.123 & & \\
\hline
\end{tabular}


Table A10. Cont.

\begin{tabular}{|c|c|c|c|c|c|c|}
\hline & \multicolumn{3}{|c|}{ Without Interaction Term } & \multicolumn{3}{|c|}{ With Interaction Term } \\
\hline $\begin{array}{l}\text { C. Middle income } \\
\text { countries }\end{array}$ & 1st regime & 2nd regime & 3rd regime & 1st regime & 2 nd regime & 3rd regime \\
\hline $\begin{array}{c}\text { Transition Value } \\
\text { GDP }\end{array}$ & $\begin{array}{c}7.08 \\
-0.099\end{array}$ & $\begin{array}{c}7.92 \\
-0.377\end{array}$ & -0.249 & $\begin{array}{c}7.71 \\
2.121\end{array}$ & $\begin{array}{c}7.86 \\
0.000\end{array}$ & $1.0 \times 10^{7}$ \\
\hline REC & -0.007 & 0.004 & -0.013 & -0.020 & 0.000 & $\begin{array}{l}-1.0 \times \\
10^{7}\end{array}$ \\
\hline URBAN & -0.237 & -0.097 & 0.010 & -0.259 & 0.000 & $1.0 \times 10^{7}$ \\
\hline BRER & -0.411 & 0.156 & 0.065 & -0.689 & 0.000 & $1.0 \times 10^{7}$ \\
\hline PIESR & 0.263 & -0.460 & 0.212 & -0.005 & 0.000 & $1.0 \times 10^{7}$ \\
\hline TACR & -0.334 & 0.353 & -0.267 & -1.104 & 0.000 & $\begin{array}{r}-1.0 \times \\
10^{7}\end{array}$ \\
\hline $\begin{array}{c}\text { FDI } \\
\text { DPIESR * FDI }\end{array}$ & 0.007 & -0.006 & 0.006 & $\begin{array}{l}0.011 \\
0.088\end{array}$ & $\begin{array}{l}0.000 \\
0.000\end{array}$ & $\begin{array}{l}1.0 \times 10^{7} \\
1.0 \times 10^{7}\end{array}$ \\
\hline $\begin{array}{l}\text { D. Lower income group } \\
\text { Transition Value } \\
\text { GDP } \\
\text { REC } \\
\text { URBAN } \\
\text { BRER } \\
\text { PIESR } \\
\text { TACR } \\
\text { FDI } \\
\text { DPIESR * FDI }\end{array}$ & $\begin{array}{l}\text { 1st regime } \\
6.34 \\
-1.0 \times 10^{10} \\
-1.0 \times 10^{10} \\
1.0 \times 10^{10} \\
1.0 \times 10^{10} \\
-1.0 \times 10^{10} \\
-1.0 \times 10^{10} \\
1.0 \times 10^{10}\end{array}$ & 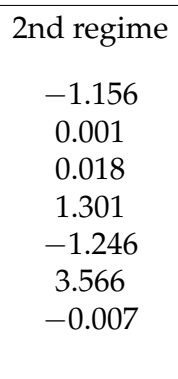 & & $\begin{array}{c}\text { 1st regime } \\
6.34 \\
-1.0 \times 10^{10} \\
-1.0 \times 10^{10} \\
1.0 \times 10^{10} \\
1.0 \times 10^{10} \\
-1.0 \times 10^{10} \\
-1.0 \times 10^{10} \\
-1.0 \times 10^{10} \\
1.0 \times 10^{10}\end{array}$ & 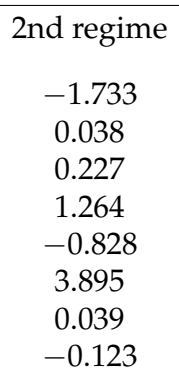 & \\
\hline $\begin{array}{l}\text { E. Higher income group } \\
\text { Transition Value }\end{array}$ & $\begin{array}{l}\text { 1st regime } \\
7.83\end{array}$ & $\begin{array}{c}\text { 2nd regime } \\
7.91\end{array}$ & 3rd regime & $\begin{array}{l}\text { 1st regime } \\
7.83\end{array}$ & $\begin{array}{c}\text { 2nd regime } \\
7.99\end{array}$ & 3rd regime \\
\hline GDP & 3.500 & 0.000 & $1.0 \times 10^{6}$ & 3.815 & 0.000 & $-1.0 \times$ \\
\hline REC & -0.037 & 0.000 & $-1.0 \times 10^{6}$ & -0.064 & 0.000 & $-1.0 \times$ \\
\hline URBAN & -0.815 & 0.000 & $1.0 \times 10^{6}$ & -0.887 & 0.000 & $-1.0 \times$ \\
\hline BRER & -2.703 & 0.000 & $-1.0 \times 10^{6}$ & -1.551 & 0.000 & $-1.0 \times$ \\
\hline PIESR & 3.313 & 0.000 & $1.0 \times 10^{6}$ & 3.486 & 0.000 & $1.0 \times 10^{6}$ \\
\hline TACR & -3.121 & 0.000 & $-1.0 \times 10^{6}$ & -2.872 & 0.000 & $-1.0 \times$ \\
\hline $\begin{array}{c}\text { FDI } \\
\text { DPIESR * FDI }\end{array}$ & 0.009 & 0.000 & $1.0 \times 10^{6}$ & $\begin{array}{c}0.101 \\
-0.186\end{array}$ & $\begin{array}{l}0.000 \\
0.000\end{array}$ & $\begin{array}{l}1.0 \times 10^{6} \\
1.0 \times 10^{6}\end{array}$ \\
\hline
\end{tabular}

\section{References}

1. Sulaiman, J.; Azman, A.; Saboori, B. The potential of renewable energy: Using the environmental Kuznets curve model. Am. J. Environ. Sci. 2013, 9, 103-112. [CrossRef]

2. Boluk, G.; Mert, M. Fossil \& renewable energy consumption, GHGs (greenhouse gases) and economic growth: Evidence from a panel of EU (European Union) countries. Energy 2014, 74, 439-446.

3. Al-Mulali, U.; Ozturk, I. The investigation of environmental Kuznets curve hypothesis in the advanced economies: The role of energy prices. Renew. Sust. Energy Rev. 2016, 54, 1622-1631. [CrossRef]

4. Ridzuan, N.H.A.M.; Marwan, N.F.; Khalid, N.; Ali, M.H.; Tseng, M.L. Effects of agriculture, renewable energy, and economic growth on carbon dioxide emissions: Evidence of the environmental Kuznets curve. Resour. Conserv. Recycl. 2020, 160, 104879. [CrossRef]

5. Raza, S.A.; Shah, N.; Khan, K.A. Residential energy environmental Kuznets curve in emerging economies: The role of economic growth, renewable energy consumption, and financial development. Environ. Sci. Pollut. Res. 2020, 27, 5620-5629. [CrossRef] [PubMed]

6. Erdogan, S.; Okumus, I.; Guzel, A.E. Revisiting the Environmental Kuznets Curve hypothesis in OECD countries: He role of renewable, non-renewable energy, and oil prices. Environ. Sci. Pollut. Res. 2020, 27, 23655-23663. [CrossRef] [PubMed]

7. Usama, A.M.; Solarin, S.A.; Salahuddin, M. The prominence of renewable and non-renewable electricity generation on the environmental Kuznets curve: A case study of Ethiopia. Energy 2020, 211, 118665. [CrossRef]

8. Murshed, M.; Haseeb, M.; Alam, M.S. The environmental Kuznets curve hypothesis for carbon and ecological footprints in south Asia: The role of renewable energy. GeoJournal 2021, 86, 1-28. [CrossRef]

9. Gyamfi, B.A.; Adedoyin, F.F.; Bein, M.A.; Bekun, F.V. Environmental implications of N-shaped environmental Kuznets curve for E7 countries. Environ. Sci. Pollut. Res. 2021, 28, 33072-33082. [CrossRef] 
10. Mahmood, H.; Alkhateeb, T.T.Y.; Tanveer, M.; Mahmoud, D.H. Testing the energy-environmental kuznets curve hypothesis in the renewable and nonrenewable energy consumption models in Egypt. Int. J. Environ. Res. Public Health 2021, 18, 7334. [CrossRef]

11. Balsalobre-Lorente, D.; Ibanez-Luzon, L.; Usman, M.; Shahbaz, M. The environmental Kuznets curve, based on the economic complexity, and the pollution haven hypothesis in PIIGS countries. Renew. Energy 2021. [CrossRef]

12. Pata, U.K. Renewable energy consumption, urbanization, financial development, income and $\mathrm{CO}_{2}$ emissions in Turkey: Testing EKC hypothesis with structural breaks. J. Clean. Prod. 2018, 187, 770-779. [CrossRef]

13. Le, T.H.; Chang, Y.; Park, D. Renewable and nonrenewable energy consumption, economic growth, and emissions: International evidence. Energy J. 2020, 41, 73-92. [CrossRef]

14. Grossman, G.M.; Krueger, A.B. Economic growth and the environment. Q. J. Econ. 1995, 110, 353-377. [CrossRef]

15. Acaravci, A.; Ozturk, I. On the relationship between energy consumption, $\mathrm{CO}_{2}$ emissions and economic growth in Europe. Energy 2010, 35, 5412-5420. [CrossRef]

16. Sarkodie, S.A.; Strezov, V. A review on environmental Kuznets curve hypothesis using bibliometric and meta-analysis. Sci. Total Environ. 2019, 649, 128-145. [CrossRef]

17. Hove, S.; Tursoy, T. An investigation of the environmental Kuznets curve in emerging economies. J. Clean. Prod. 2019, 236, 117628. [CrossRef]

18. Isik, C.; Ongan, S.; Ozdemir, D.; Ahmad, M.; Irfan, M.; Alvarado, R.; Ongan, A. The increases and decreases of the environment Kuznets curve (EKC) for 8 OECD countries. Environ. Sci. Pollut. Res. 2021, 28, 28535-28543. [CrossRef]

19. Dogan, E.; Ulucak, R.; Kocak, E.; Isik, C. The use of ecological footprint in estimating the environmental Kuznets curve hypothesis for BRICST by considering cross-section dependence and heterogeneity. Sci. Total Environ. 2020, 723, 138063. [CrossRef]

20. Ahmad, M.; Muslija, A.; Satrovic, E. Does economic prosperity lead to environmental sustainability in developing economies? Environmental Kuznets curve theory. Environ. Sci. Pollut. Res. 2021, 28, 22588-22601. [CrossRef] [PubMed]

21. Altinoz, B.; Apergis, N.; Aslan, A. Energy consumption, carbon dioxide emissions and economic growth: Fresh evidence from panel quantile regressions. Energy Res. Lett. 2020, 1, 17075. [CrossRef]

22. Apergis, N.; Polemis, M. Decomposing supply shocks in the US electricity industry: Evidence from a time-varying bayesian panel vector autoregression model. J. Energy Mark. 2020, 13. [CrossRef]

23. Murshed, M.; Ferdaus, J.; Rashid, S.; Tanha, M.M.; Islam, M.J. The Environmental Kuznets curve hypothesis for deforestation in Bangladesh: An ARDL analysis with multiple structural breaks. Energy Ecol. Environ. 2021, 6, 111-132. [CrossRef]

24. Dogru, T.; Bulut, U.; Kocak, E.; Isik, C.; Suess, C.; Sirakaya-Turk, E. The nexus between tourism, economic growth, renewable energy consumption, and carbon dioxide emissions: Contemporary evidence from OECD countries. Environ. Sci. Pollut. Res. 2020, 27, 40931-40948. [CrossRef]

25. Isik, C.; Ahmad, M.; Pata, U.K.; Ongan, S.; Radulescu, M.; Adedoyin, F.F.; Bayraktaroglu, E.; Aydın, S.; Ongan, A. An evaluation of the tourism-1nduced environmental Kuznets curve (T-EKC) hypothesis: Evidence from G7 countries. Sustainability 2020, 12, 9150. [CrossRef]

26. Ongan, S.; Isik, C.; Ozdemir, D. Economic growth and environmental degradation: Evidence from the US case environmental Kuznets curve hypothesis with application of decomposition. J. Environ. Econ. Policy 2021, 10, 14-21. [CrossRef]

27. Alvarado, R.; Tillaguango, B.; Lopez-Sanchez, M.; Ponce, P.; Işık, C. Heterogeneous impact of natural resources on income inequality: The role of the shadow economy and human capital index. Econ. Anal. Policy 2021, 69, 690-704. [CrossRef]

28. Shahzad, U.; Radulescu, M.; Rahim, S.; Isik, C.; Yousaf, Z.; Ionescu, S.A. Do environment-related policy instruments and technologies facilitate renewable energy generation? exploring the contextual evidence from developed economies. Energies 2021, 14, 690. [CrossRef]

29. Pethig, R. Pollution, welfare, and environmental policy in the theory of comparative advantage. J. Environ. Econ. Manag. 1976, 2, 160-169. [CrossRef]

30. Walter, I.; Ugelow, J.L. Environmental policies in developing countries. Ambio 1979, 8, 102-109.

31. Bommer, R. Environmental policy and industrial competitiveness: The pollution? Haven hypothesis reconsidered. Rev. Int. Econ. 1999, 7, 342-355. [CrossRef]

32. Rana, R.; Sharma, M. Dynamic causality testing for EKC hypothesis, pollution haven hypothesis and international trade in India. J. Int. Trade Econ. Dev. 2019, 28, 348-364. [CrossRef]

33. Shen, J.; Wang, S.; Liu, W.; Chu, J. Does migration of pollution-intensive industries impact environmental efficiency? Evidence supporting pollution haven hypothesis. J. Environ. Manag. 2019, 242, 142-152. [CrossRef]

34. Wang, X.; Zhang, C.; Zhang, Z. Pollution haven or porter? The impact of environmental regulation on location choices of pollution-intensive firms in China. J. Environ. Manag. 2019, 248, 109248. [CrossRef]

35. Nathaniel, S.; Aguegboh, E.; Iheonu, C.; Sharma, G.; Shah, M. Energy consumption, FDI, and urbanization linkage in coastal Mediterranean countries: Re-assessing the pollution haven hypothesis. Environ. Sci. Pollut. Res. 2020, 27, 35474-35487. [CrossRef]

36. Guzel, A.E.; Okumus, I. Revisiting the pollution haven hypothesis in ASEAN-5 countries: New insights from panel data analysis. Environ. Sci. Pollut. Res. 2020, 27, 18157-18167. [CrossRef] [PubMed]

37. Sadik-Zada, E.R.; Ferrari, M. Environmental policy stringency, technical progress and pollution haven hypothesis. Sustainability 2020, 12, 3880. [CrossRef]

38. Singhania, M.; Saini, N. Demystifying pollution haven hypothesis: Role of FDI. J. Bus. Res. 2021, 123, 516-528. [CrossRef] 
39. Bulus, G.C.; Koc, S. The effects of FDI and government expenditures on environmental pollution in Korea: The pollution haven hypothesis revisited. Environ. Sci. Pollut. Res. 2021, 28, 38238-38253. [CrossRef] [PubMed]

40. Bulut, U.; Ucler, G.; Inglesi-Lotz, R. Does the pollution haven hypothesis prevail in Turkey? Empirical evidence from nonlinear smooth transition models. Environ. Sci. Pollut. Res. 2021, 28, 38563-38572. [CrossRef] [PubMed]

41. Ranocchia, C.; Lambertini, L. Porter hypothesis vs pollution haven hypothesis: Can there be environmental policies getting two eggs in one basket? Environ. Resour. Econ. 2021, 78, 177-199. [CrossRef]

42. Zhang, K.; Wang, X. Pollution haven hypothesis of global $\mathrm{CO}_{2}, \mathrm{SO} 2$, NOx-Evidence from 43 economies and 56 sectors. Int. J. Environ. Res. Public Health 2021, 18, 6552. [CrossRef] [PubMed]

43. Birdsall, N.; Wheeler, D. Trade policy and industrial pollution in Latin America: Where are the pollution havens? J. Environ. Dev. 1993, 2, 137-149. [CrossRef]

44. Zhang, C.; Zhou, X. Does foreign direct investment lead to lower $\mathrm{CO}_{2}$ emissions? Evidence from a regional analysis in China. Renew. Sust. Energy Rev. 2016, 58, 943-951. [CrossRef]

45. Liu, Y.; Hao, Y.; Gao, Y. The environmental consequences of domestic and foreign investment: Evidence from China. Energy Policy 2017, 108, 271-280. [CrossRef]

46. Matthew, C.; Neumayer, E. Examining the impacts of demographic factors on air pollution. Popul. Environ. 2004, $26,5-21$.

47. Liddle, B.; Lung, S. Age-structure, urbanization, and climate change in developed countries: Revisiting STIRPAT for disaggregated population and consumption-related environmental impacts. Popul. Environ. 2010, 31, 317-343. [CrossRef]

48. Poumanyvong, P.; Kaneko, S. Does urbanization lead to less energy use and lower $\mathrm{CO}_{2}$ emissions? A cross-country analysis. Ecol. Econ. 2010, 70, 434-444. [CrossRef]

49. Martinez-Zarzoso, I.; Maruotti, A. The impact of urbanization on $\mathrm{CO}_{2}$ emissions: Evidence from developing countries. Ecol. Econ. 2011, 70, 1344-1353. [CrossRef]

50. Bekhet, H.A.; Othman, N.S. Impact of urbanization growth on Malaysia $\mathrm{CO}_{2}$ emissions: Evidence from the dynamic relationship. J. Clean. Prod. 2017, 154, 374-388. [CrossRef]

51. Zhu, H.M.; You, W.H.; Zeng, Z.F. Urbanization and $\mathrm{CO}_{2}$ emissions: A semi-parametric panel data analysis. Econ. Lett. 2012, 117, 848-850. [CrossRef]

52. Tucker, M. Carbon dioxide emissions and global GDP. Ecol. Econ. 1995, 15, 215-223. [CrossRef]

53. Onafowora, O.A.; Owoye, O. Bounds testing approach to analysis of the environment Kuznets curve hypothesis. Energy Econ. 2014, 44, 47-62. [CrossRef]

54. Apergis, N. Environmental Kuznets curves: New evidence on both panel and country-level $\mathrm{CO}_{2}$ emissions. Energy Econ. 2016, 54, 263-271. [CrossRef]

55. Youssef, A.B.; Hammoudeh, S.; Omri, A. Simultaneity modeling analysis of the environmental Kuznets curve hypothesis. Energy Econ. 2016, 60, 266-274. [CrossRef]

56. Churchill, S.A.; Inekwe, J.; Ivanovski, K.; Smyth, R. The environmental Kuznets curve in the OECD: 1870-2014. Energy Econ. 2018, 75, 389-399. [CrossRef]

57. Fan, Y.; Liu, L.C.; Wu, G.; Wei, Y.M. Analyzing impact factors of $\mathrm{CO}_{2}$ emissions using the STIRPAT model. Environ. Impact Assess. Rev. 2006, 26, 377-395. [CrossRef]

58. Nasir, M.A.; Huynh, T.L.D.; Tram, H.T.X. Role of financial development, economic growth \& foreign direct investment in driving climate change: A case of emerging ASEAN. J. Environ. Manag. 2019, 242, 131-141.

59. Fadly, D. Low-carbon transition: Private sector investment in renewable energy projects in developing countries. World Dev. 2019, 122, 552-569. [CrossRef]

60. Brunnschweiler, C.N. Finance for renewable energy: An empirical analysis of developing and transition economies. Environ. Dev. Econ. 2010, 15, 241-274. [CrossRef]

61. Dulal, H.B.; Shah, K.U.; Sapkota, C.; Uma, G.; Kandel, B.R. Renewable energy diffusion in Asia: Can it happen without government support? Energy Policy 2013, 59, 301-311. [CrossRef]

62. Keohane, N.O.; Revesz, R.L.; Stavins, R.N. The choice of regulatory instruments in environmental policy. Harvard Environ. Lit. Rev. 1998, 22, 313-367.

63. Loris, N.D. Economic Freedom, Energy, and Development; Miller, A.T., Kim, A.B., Eds.; The Heritage Foundation: Washington, DC, USA, 2015; pp. 57-68.

64. Sys, C.; Vanelslander, T.; Driaenssens, M.; Van Rillaer, I. International emission regulation in sea transport: Economic feasibility and impact. Transp. Res. D Transp. Environ. 2016, 45, 139-151. [CrossRef]

65. Vob, J.P. Innovation processes in governance: The development of 'emissions trading' as a new policy instrument. Sci. Public Policy 2007, 34, 329-343.

66. Colvin, R.M.; Kemp, L.; Talberg, A.; De Castella, C.; Downie, C.; Friel, S.; Platow, M.J. Learning from the climate change debate to avoid polarization on negative emissions. Environ. Commun. 2020, 14, 23-35. [CrossRef]

67. Gonzalez, A.; Terasvirta, T.; Van Dijk, D. Panel Smooth Transition Regression Models; Research Paper Series 165; Quantitative Finance Research Centre, University of Technology: Sydney, NSW, Australia, 2005.

68. Fok, D.; Van Dijk, D.; Franses, P.H. A multi-level panel STAR model for US manufacturing sectors. J. Appl. Econom. 2005, 20, 811-827. [CrossRef]

69. Granger, C.W.J.; Terasvirta, T. Modelling nonlinear economic relationships. OUP Cat. 1993, 25, 56-89. 
70. Terasvirta, T. Specification, estimation, and evaluation of smooth transition autoregressive models. J. Am. Stat. Assoc. 1994, 89, 208-218.

71. Jansen, E.S.; Teräsvirta, T. Testing parameter constancy and super exogeneity in econometric equation. Oxf. Bull. Econ. Stat. 1996, 58, 735-763. [CrossRef]

72. Levin, A.; Lin, C.F.; Chu, C.S.J. Unit root tests in panel data: Asymptotic and finite-sample properties. J. Econom. 2002, 108, 1-24. [CrossRef]

73. Barra, C.; Zotti, R. Investigating the non-linearity between national income and environmental pollution: International evidence of Kuznets curve. Environ. Econ. Policy Stud. 2018, 20, 179-210. [CrossRef]

74. Kearsley, A.; Riddel, M. A further inquiry into the pollution haven hypothesis and the environmental Kuznets curve. Ecol. Econ. 2010, 69, 905-919. [CrossRef]

75. Arouri, M.E.H.; Youssef, A.B.; M'henni, H.; Rault, C. Energy consumption, economic growth and $\mathrm{CO}_{2}$ emissions in Middle East and north African countries. Energy Policy 2012, 45, 342-349. [CrossRef] 